\title{
المَوضُوعيَّة في دراسة الأديان: إشكالية المفهوم والمصطلح
}

\section{OBJECTIVITY IN RELIGIOUS STUDY: PROBLEM OF CONCEPT AND TERMINOLOGY}

\section{Abdullah Ahmed Mubarak Bawadi}

Department of Creed \& Contemporary Doctrines. College of Shariah and Fundamentals of Religion. King Khalid University. Asir - Abha. Kingdom of Saudi Arabia.

\section{Email: aabawadi@kku.edu.sa}

\begin{abstract}
Khulasah
Makalah ini menyentuh permasalahan konsep objektiviti dan potensi untuk diaplikasikan menurut al-Quran al-Karim dan sains sosial serta kemanusiaan. Ia turut memfokuskan isu asas, prinsip dan penyelesaian kepada permasalahan objektiviti yang terkandung dalam kajian agama menurut al-Quran, di samping membincangkan isu penetapan hukum syariah. Kajian ini menyenaraikan perspektif syariah bersumberkan al-Quran yang berkaitan dengan semua isu tersebut. Perspektif ini akan mematahkan konsep Barat mengenai maksud sebenar objektiviti, sekaligus mengkritik metodologi yang digunakan dalam menjadikan terminologi kontemporari sebagai sandaran untuk menetapkan keputusan dalam isu-isu syariah. Kajian ini juga akan mengulas pendapat tentang pencanggahan objektiviti dengan ideologi, penetapan hukum-hakam, pemisahan agama daripada diri, kritikan dan pegangan agama, serta kerelatifan kebenaran. Tujuan kajian ini dijalankan untuk menekankan kepentingan menjaga terminologi syariah dalam membuat keputusan saintifik, termasuklah istilah objektiviti dan mengelakkan kesalahan saintifik yang berkaitan dengan istilah tersebut. Penulis menggunakan pendekatan induktif untuk mengkaji permasalahan kajian dengan meneliti artikel-artikel saintifik daripada sumber pemikiran Islam. Selain itu, penulis turut memilih kaedah
\end{abstract}


kritikan untuk membincangkan beberapa permasalahan yang berkait dengan persoalan kajian. Hasil dapatan kajian jelas menunjukkan pembuktian kebenaran dan konsep objektiviti dalam kajian agama, di samping potensi untuk mengaplikasikannya mengikut aturan yang terdiri daripada asas, prinsip, dan penetapan hukum syariah.

Kata kunci: agama; objektiviti; permasalahan; konsep; terminologi.

\begin{abstract}
The article touched on the problematic concept of objectivity and its possibility to be applied as in the Holy Qur'an, social and human sciences. It also focuses on the fundamental issues, principles and solutions to the objectivity problems contained in the religious studies in the Qur'an, as well as discussing the issues of Shari ah law. The research showed that the Shari 'ah opinion derived from the Holy Qur'an in all these cases which invalidate the Western concept of the fact of objectivity. It also criticized the method of relying on the contemporary terms in taking decisions of Sharīah cases. It also analysed the opinion of the discrepancy between the objectivity, the ideological and tradition judgments, the religious criticism, self-abstraction and the religious belief, the relativity of truth and the religious knowledge. The research aimed to emphasize the importance of the commitment to use the Shari'ah terminologies in making scientific decisions including the term of objectivity and distinguishing the scientific mistakes related to this term. In treating this topic, this article used the inductive method, delving into the scientific articles in the Islamic thoughts. Furthermore, it used the critical method to discuss some issues related to the problem statement of the research. The results confirm the truth of objectivity and its concept in religious studies, the possibility of applying it according to a system of principles, fundamentals and Sharīah Law legitimation.
\end{abstract}


Abdullah Ahmed, "Objectivity in Religious Study," Afkār Vol. 20 Issue 1 (2018): 229-284

Keywords: religions; objectivity; problems; concept; terminology.

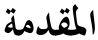

إن من أهم الإشكاليات المنهجية التي تواجه دراسة علم الأديان في العصر الحاضر مشكلة الموضوعية "objectivity" والالتزام بالحياديَّة

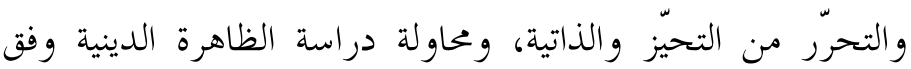
منهج محايد وبطريقة موضوعية بعيداً عن المؤثرات الفكرية و الأيديولوجية والثقافية والوجدانية للباحث.

لقد كان القرآن الكريم هو المصدر الذي استلهم منه مؤرَّخة الأديان المسلمون المنهجية في دراستهم للأديان؛ والمرشد الذي استرشدوا بتعاليمه في دراسة الظاهرة الدينية، و نظراً لظروف البيئة المجتمعية ونشوء الجدل الديني والصراع الفكري في المجتمعات الإسلامية والوقوف على حضارات دينية وثقافية مختلفة تعدّدت مناهجهم في دراسة الأديان ما بين منهج جدلي نقدي جدلي كلامي، ومنهج جدلي مقارن، ومنهج وصفي تاريخي، مما يؤكد أسبقية الحضارة الإسلامية في الاهتمام بدراسة علم الأديان وخضوعه لمنهجيات خاصة وفق رؤية إسلامية متميزة، ساهمت فيما بعد في إثراء الفكر الحضاري والمعرفي الإنساني وشكّلت حلقة مهمّة في تاريخ دراسة الأديان في الفكر الغربي.

وعلى الرغم من أصالة ومنهجية دراسة الأديان في الفكر الإسلامي؛ إلا إنه تبرز تساؤلات عن مدى موضوعية تلك الدراسة 
Abdullah Ahmed, "Objectivity in Religious Study," Afkār Vol. 20 Issue 1 (2018): 229-284

وجدواها في البحث العلمي. إذ إن الموضوعية تُعدُّ أبرز خصائص

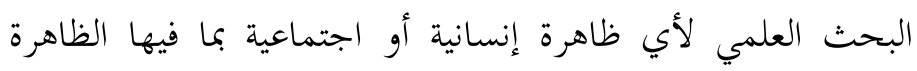

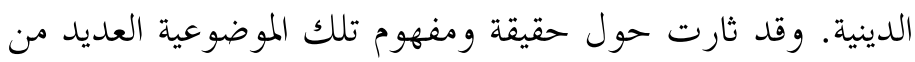

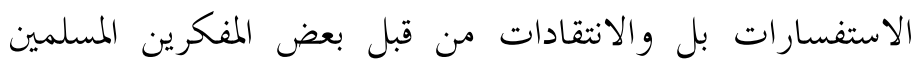
و الغربيين سواء في العلوم الاجتماعية والإنسانية أو في علم الأديان، ومحصّل تلك الاستفسارات والانتقادات تدور حول إشكالية المفهوم ومشروعية المصطلح ومدى مصداقية وإمكانية تطبيقه في دراسة الظاهرة الدينية، وهل يمكن للباحث أن يتحلَّلى بموضوعية مثالية متجردة من التحيزات والأحكام المسبقة والتأثر بدوافعه وتثقافته لئه ومعتقده الديني? وهل يمكن لتلك الموضوعية أن تكون محايدة ومتجرَّدة من

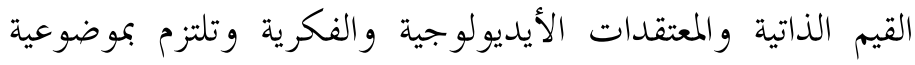
علمية؟ وإذا كان علماء المسلمين قد التزموا بالموضوعية في دراستهم للأديان - كما نزعم- فما مصدر تلك الموضوعية؟ وما حقيقتهاء ومفهومها؟ وهل تختلف عن الموضوعية في الفكر الغربي أم أهما موضوعية تابعة وتقليدية من حيث المفهوم والماهية لما كتبه وسار

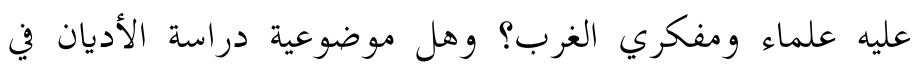

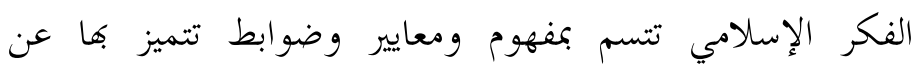
الموضوعية في الفكر الغربي؟ وبناء على هذه الاستفسارات والتساؤلات جاء هذا البحث ليبرز حقيقة ومفهوم الموضوعية في 
Abdullah Ahmed, "Objectivity in Religious Study," Afkār Vol. 20 Issue 1 (2018): 229-284

دراسة الأديان في الفكر الإسلامي من حيث الإجابة عن إشكالية

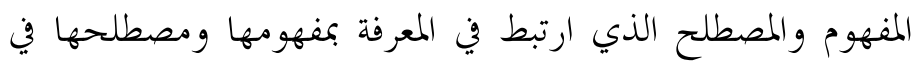

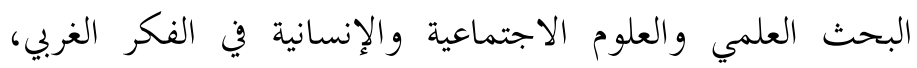

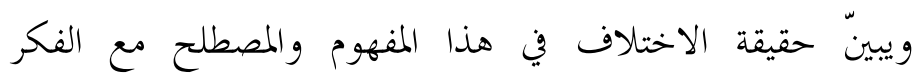
الإسلامي.

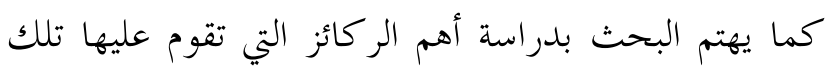

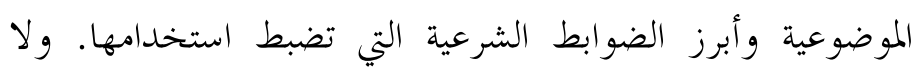

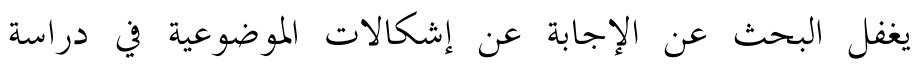

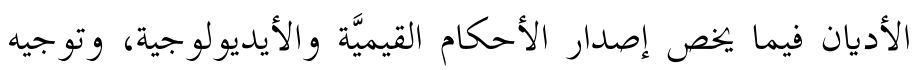

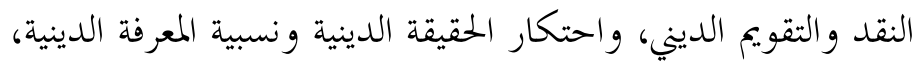
ودعوى التجرُّد من الذاتية والمعتقد الديني. تكمن أهمية البحث في كونه يهتم ببيان وتوضيح مفهوم وحقيقة الموضوعية في دراسة الأديان في الفكر الإسلامي وتمايزها

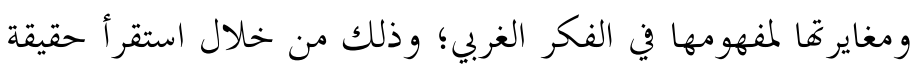
ومفهوم الموضوعية في دراسة الأديان في القرآن الكريم، كونه

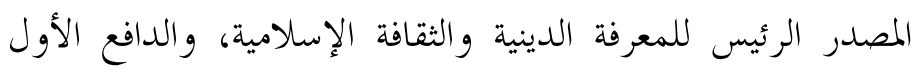

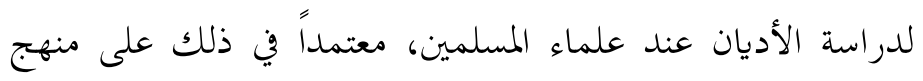
علمي يقوم على الاستقراء والتتبع، مع التحليل والدراسة والنقد لما لمان

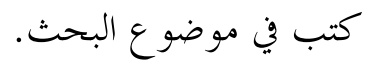


Abdullah Ahmed, "Objectivity in Religious Study," Afkār Vol. 20 Issue 1 (2018): 229-284

لقد وقفت أثناء بحثي عن الدراسات السابقة في موضوع البحث على دراسات مطبوعة ومقالات منشورة في بجلات علمية محكمة وغيرها. ومن أهم الدراسات التي وقفت عليها ورات ولها تعلّق مباشر بصميم البحث؛ بحث بعنوان "الموضوعية في دراسة الأديان"

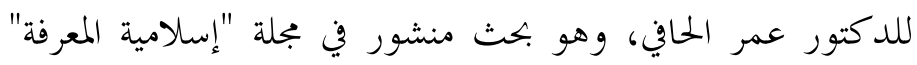
التي يصدرها المعهد العالمي للفكر الإسلامي بأمريكا، وقد الهت إنتم الباحث في بحثه بالحديث عن مفهوم الموضوعية في دراسة الأديان والأسس العقدية والفكرية والأخلاقية للموضوعية في القرآن

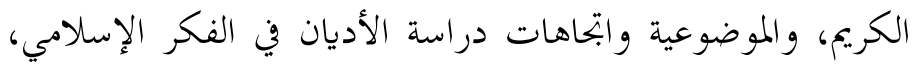

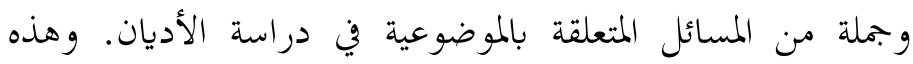

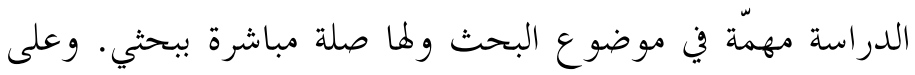

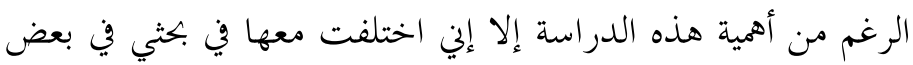

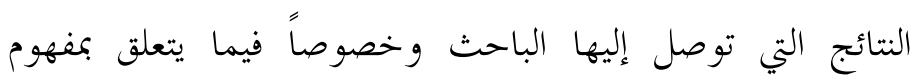

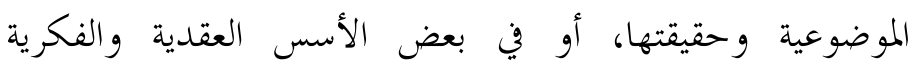

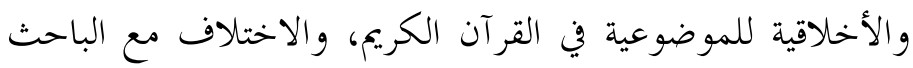
في الاستدلال ببعض نصوص القرآن وتوظيفها بطريقة غير مرضية. كما اختلفت معه في تقرير عدد من القضايا في البحث ناقشتها في

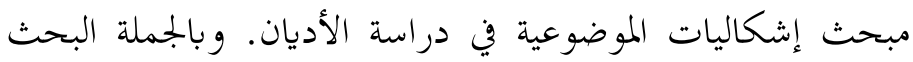

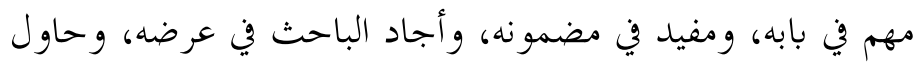

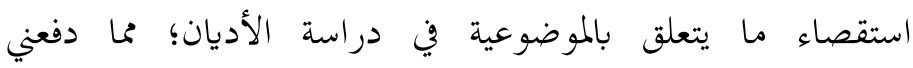


Abdullah Ahmed, "Objectivity in Religious Study," Afkār Vol. 20 Issue 1

للاستفادة منه في بعض المواضع في بكثي، إلا أن ما طرحه من

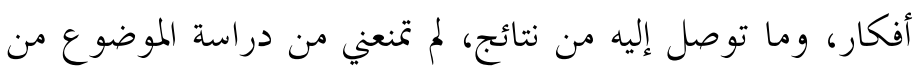
وجهة نظر أخرى وبطريقة مغايرة لإثراء الموضوع وتكميله،

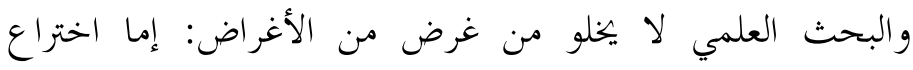

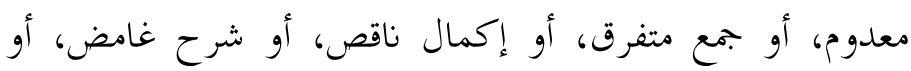

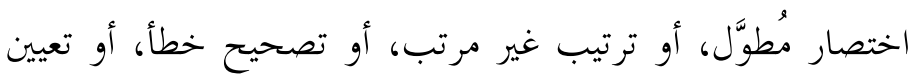

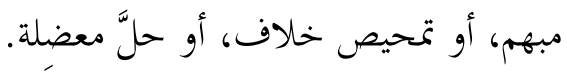

\section{المبحث الأول :الموضوعية: وإشكالية المفهوم والمصطلح المطلب الأول: الموضوعية في المفهوم اللغوي}

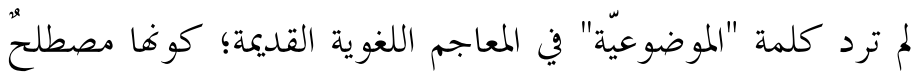
حادث" ظهر في غهاية القرن التاسع عشر عندما نبّه العالم الفرنسي

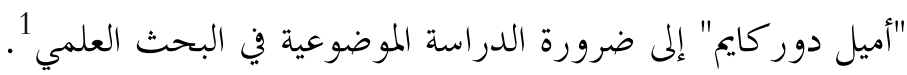
و اقتصرت تلك المعاجم على الجذذر اللغوي للموضوعية وهو الفعل:

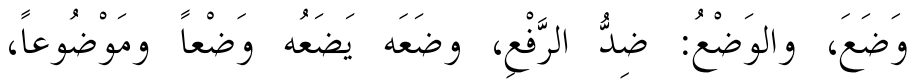

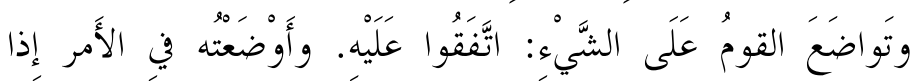

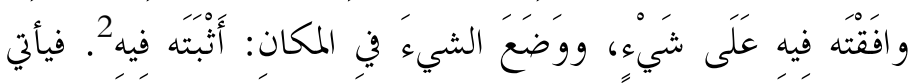
الفعل وضع: بمعنى إثبات الشيء، و والاتفاق عليه.

${ }^{1}$ Rajā' Wahìid Duwaydarī, al-Bahts al-'Ilmì Asāsiyātuhu al-Nadhriyyah wa Mumārasatuh al-'Ilmiyah, ed. 1 (Beirut: Dār al-Fikr al-Mu āṣir, 1421H/2000), 232.

${ }^{2}$ Abū al-Fadhl Muhammad ibn Mukarram ibn Manẓūr, Lisān al- 'Arab, ed. 3, vol. 8 (Beirut: Dār Șādir, 1414H), 396. 
Abdullah Ahmed, "Objectivity in Religious Study," Afkār Vol. 20 Issue 1

وأما في المعاجم اللغوية المعاصرة فقد ذكرت معنى "الموضوعية" في اللغة وفي المفهوم الاصطلاحي المعاصر المتداول في الفلسفة. حيث ذكر "معجم اللغة العربية المعاصرة" أن الموضوعية:

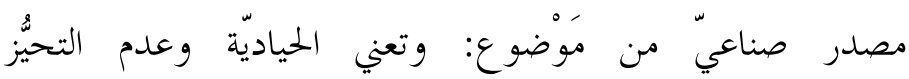

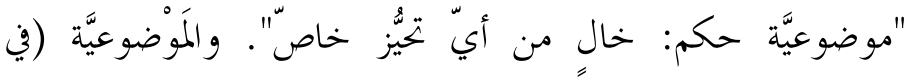

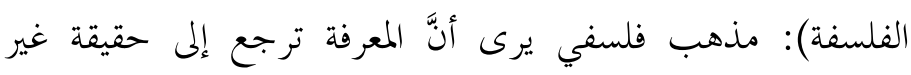

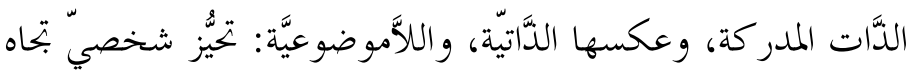

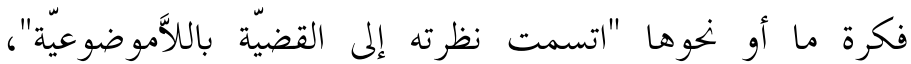

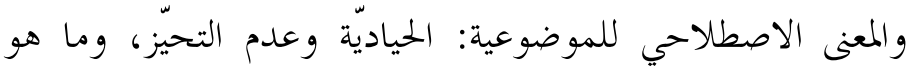

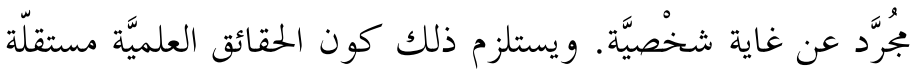

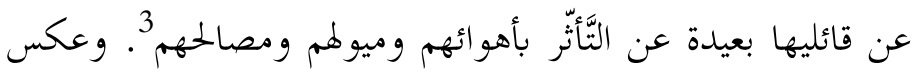

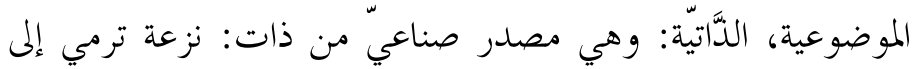

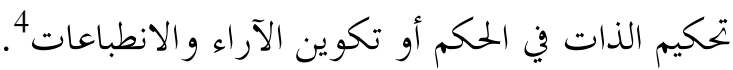

\section{المطلب الثاني: الموضوعية في الاصطلاح العام:}

الموضوعية (objectivity): "صفة أو حالة كون الشيء أو الموجود المورد

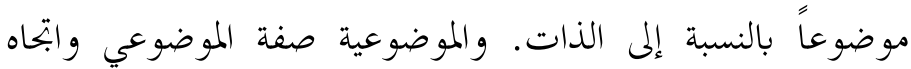
عقلي لرؤية الأشياء كما هي عليه في الواقع، فلا يشوهها بالنظر

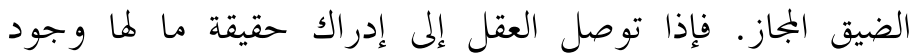

3 Aḥmad Mukhtār 'Umar, Mu'jam al-Lughah al-'Arabiyyah alMu'asșirah, ed. 1, vol. 3 (Cairo: 'Ālim al-Kutub, 1429H/2008), 24572458.

${ }^{4}$ Ibid., vol. 1, 802. 
Abdullah Ahmed, "Objectivity in Religious Study," Afkār Vol. 20 Issue 1 (2018): 229-284

و واقع، قائمة بذاهما ومستقلة عن الذات التي تدركها كانت تلك

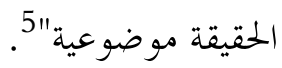

وفي المصطلح تطلق الموضوعية "للدلالة على المنهج أو الأسلوب المجرد عن المؤثرات الذاتية؛ لأن ذات الشيء هي حقيقته

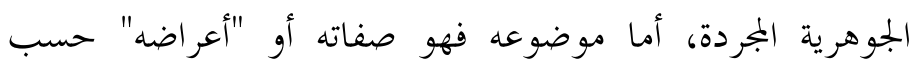
مصطلحات المناطقة. وقد استخدم هذان الاصطلاحان "الذاتية"، و"الموضوعية" في مناهج البحث العلمي للتعبير عن أسلوبين أو منهجين متضادين لأحدهما يعتمد على النظرة الشخصية للباحث "الذاتية"، والآخر يعتمد على الحقائق المجردة "الموضوعية"' .

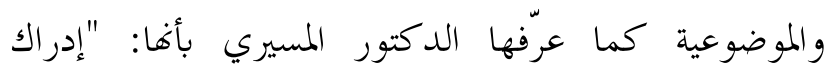
الأشياء على ما هي عليه دون أن يشوهها نظرة ضيقة أو أهواء أو ميول أو مصالح أو تحيزات أو حب أو كره"7. أي تستند الأحكام إلى النظر إلى الحقائق على أساس العقل. وبعبارة أخرى تعني

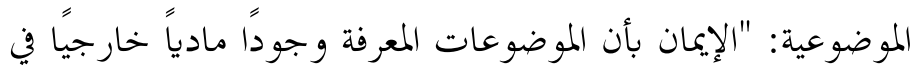
الواقع، و وأن الحقائق يجب أن تظل مستقلة عن قائليها ومدركيها....وأن الذهن يستطيع أن يصل إلى إدراك الحقيقة الواقعية

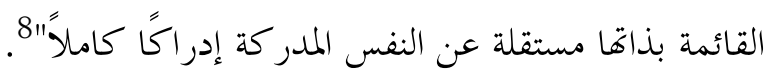

${ }^{5}$ Al-Mawsū'ah al-'Arabiyyah, al-Mawd̄u' 'yyah, accessed 12 Oct 2017, https://www.arab-ency.com/ar.

${ }^{6}$ Muḥammad Șāmil al-Salmī, Manhaj Kitābah al-Tārīkh al-Islāmī, ed. 1 (al-Damām: Dār Ibn Jawzì, 1429H), 133-134.

7 'Abd al-Wahhāb al-Musayrī, Mawsū'ah al-Yahūd wa al-Yahūdiyyah wa al-Ṣahyūniyyah, ed. 1, vol. 1 (Cairo: Dār al-Shurūq, 1999), 95.

${ }^{8}$ Ibid., 95. 
Abdullah Ahmed, "Objectivity in Religious Study," Afkār Vol. 20 Issue 1 (2018): 229-284

والموضوعية في مناهج البحث تعني: "الالتزام بالنص

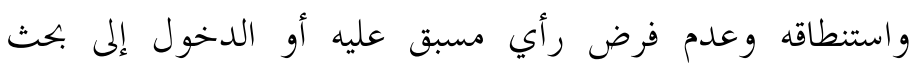

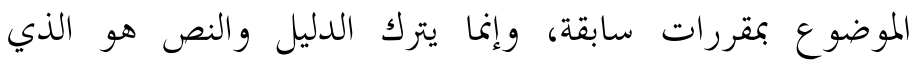

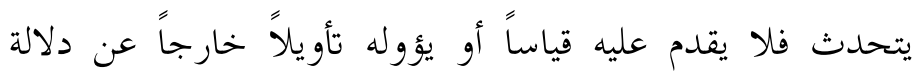
النص وسياقه، والموضوعية الحقة هي مراعاة كل العناصر التي لها

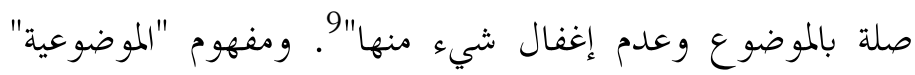
ارتبط به في مناهج البحث العلمي مفهومين آخرين، وهما: مفهوم

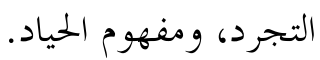

والتجرُّد: يعني الانفصال عن كل كل المؤثرات النفسية والاجتماعية، و كذلك التصورات السابقة من العقائد أو الأهواء والميول والرغبات، وهو بهذا المعنى مر ادف لمر ادهم بالموضوعية 10.

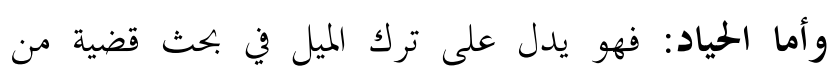
القضايا، والوقوف موقف العدل والإنصاف، أو التوقف في المسألة

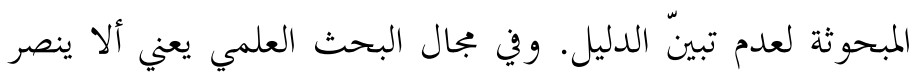

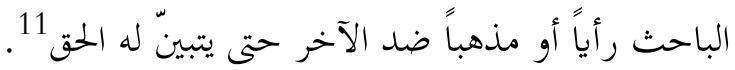

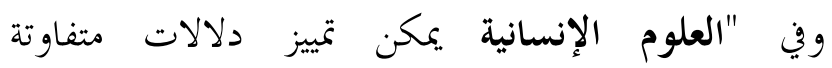

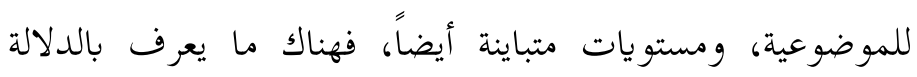

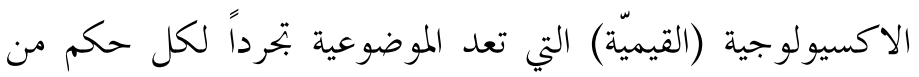

${ }^{9}$ Al-Salmī, Manhaj Kitābah al-Tārīkh al-Islāmīi, 135.

${ }^{10}$ Ibid.,136.

${ }^{11}$ Ibid.,142. 
Abdullah Ahmed, "Objectivity in Religious Study," Afkār Vol. 20 Issue 1

أحكام القيمة. والدلالة الإبستمولوجية (المعرفية) وتعنى بالصلة بين

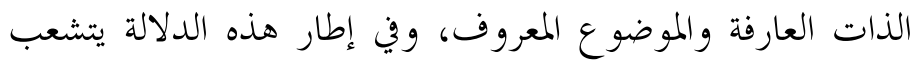
النزاع بين ضروب المثالية (Idealism)، والواقعية (Realism)، و وبين

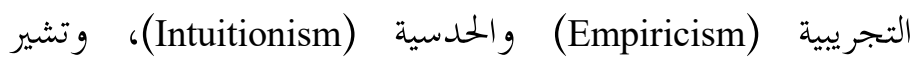
دلالتها الثقافية إلى الاتفاق والتواضع حول جملة الشروط والتدابير

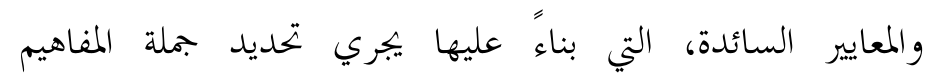

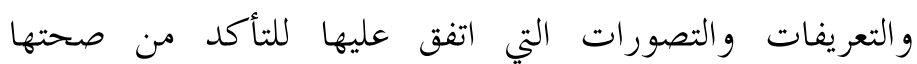
و وإثباتما"12.

وجرت العادة في بحث مشكلة الموضوعية في العلوم الإنسانية

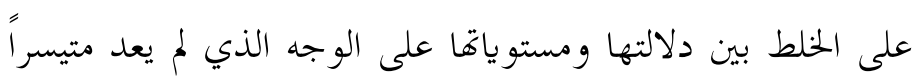

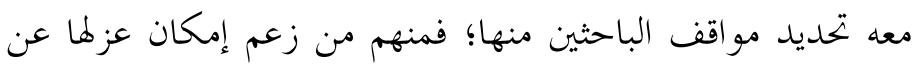

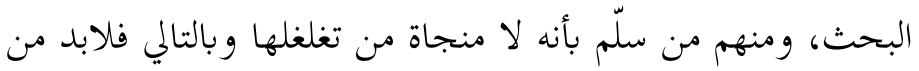

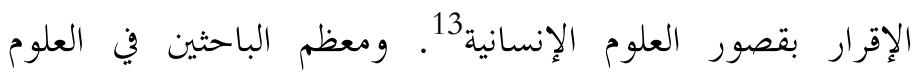

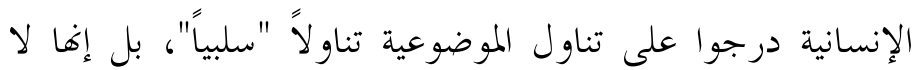

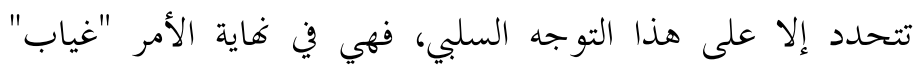
لكل عوامل التحيّز، و "كف" لتأثيرها 14

وإلى هذا التحديد السلبي للموضوعية يذهب لفي علماء الاجتماع إلى أن الموضوعية تشير "إلى غياب كل عوامل التحيّ

${ }^{12}$ Al-Mawsū 'ah al-'Arabiyyah, al-Mawdī' 'iyyah.

${ }^{13}$ Șalāḥ Qansūh, al-Mawḍ̂̀'iyyah fí al-'Ulūm al-Insāniyyah, ed. 2 (Beirut: Dār al-Tanwìi, 1984), 71.

${ }^{14}$ Ibid., 65. 
وكف تأثيرها وعزل كل ما من شأنه أن يؤثر على الباحث في

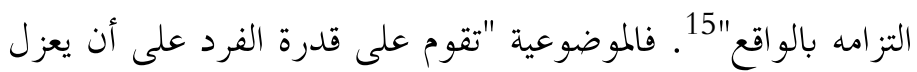

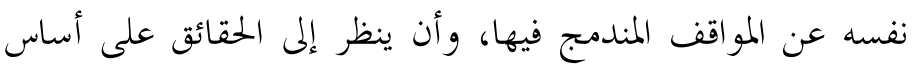

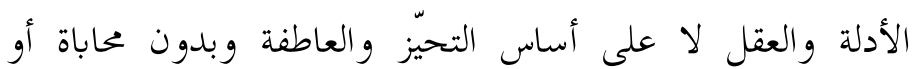

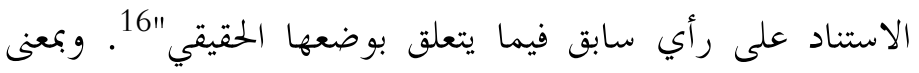

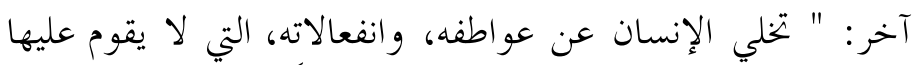

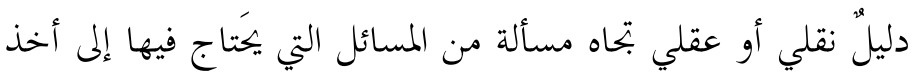

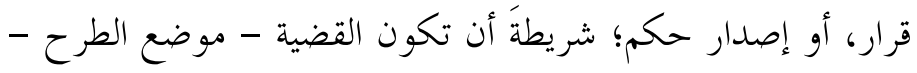

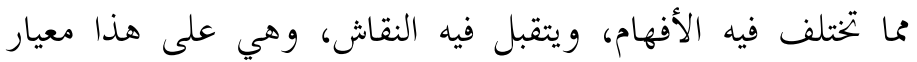

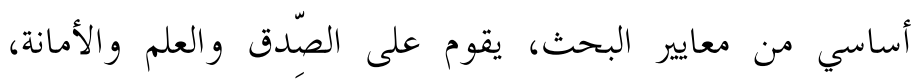
والبعد عن الأهواء الشخصية 17".

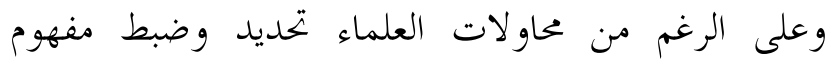

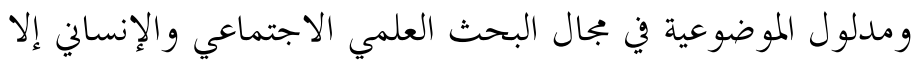

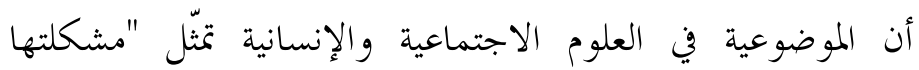

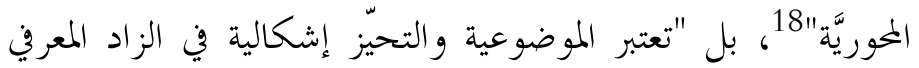

${ }^{15}$ Al-Mawsū 'ah al- 'Arabiyyah, al-Mawdū' 'iyyah.

16 Ahmad Zakì Badwí, Mu'jam al-'Ulüm al-Ijtimā'iyyah (Beirut: Maktabah Lubnān, t.t.), 290. See also: Ibrāhīm Madkūr, Mu 'jam al'Ulūm al-Insāniyyah (Cairo: al-Hay'ah al-'Āmah al-Mișriyyah li alKutub, t.t.), 183.

17 'Abd al-Rahmān ibn Salih 'Abd Allāh, al-Mawdù 'iyyah fí al-'Ulūm al-Tarbawiyyah Ru'yah Islāmiyyah, ed. 1 (Jeddah: Dār al-Manārah, 1407H), 6.

${ }^{18}$ Qansūh, al-Mawdị 'iyyah fì al- 'Ulūm al-Insāniyyah, 74. 
Abdullah Ahmed, "Objectivity in Religious Study," Afkār Vol. 20 Issue 1 (2018): 229-284

للعلوم الاجتماعية والإنسانية المعاصرة وقضية شائكة استعصى البث فيها على الذين تناولوها بالتحليل و المناقشة" 19.

\section{المطلب الثالث: الموضوعيّة في القر آن الكريم:}

فإذا كانت الموضوعية لم ترد في المعاجم اللغوية القديمة فإنها كذلك لم تأت في القرآن الكريم بهذا المصطلح والمفهوم الاصطلاحي. و وإنا ورد فعلها الاشتقاقي وهو "وضَعَعَ" وقد استعمل الوَضعُعُ في القرآن

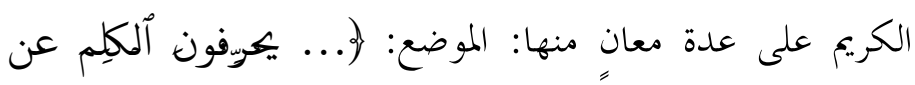

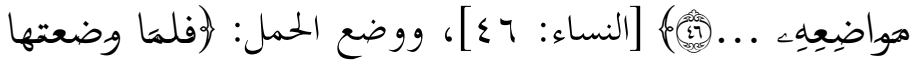

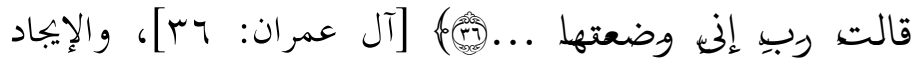

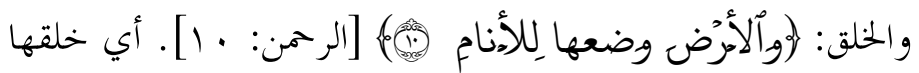

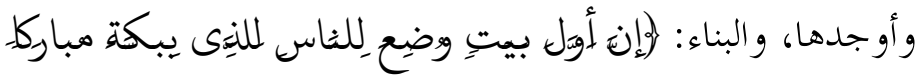

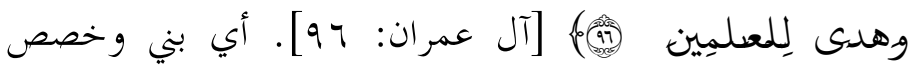
للعبادة. كما يأتي الوضع في القرآن على معنى بث الشيء في النفس

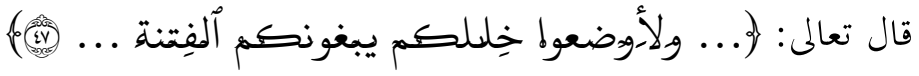

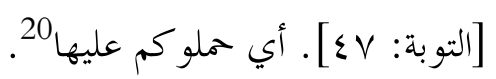

${ }^{19}$ Maḥmūd al-Zawādi, Mulāmah al-Tahayyiz wa al-Mawḍ̄ 'iyyah fì alFikr al-Ijtimā 'iyyah al-Insāni al-Gharbì al-Khaldūnì, Ishkāliyyah alTahayyiz Ru'yah Ma'rifiyyah wa Da'wah li al-Ijtihād, ed. 2, vol. 2 (America: al-Ma had al-'Ālami li al-Fikr al-Islāmí, 1418H/1997), 14-15.

${ }^{20}$ Al-Rāghib al-Aṣhfahāni, Abū al-Qāsim al-Ḥusayn ibn Muhammad, al-Mufradāt fì Gharīb al-Qur'ān, ed. Șafwān 'Adnān al-Dawdì, ed. 1 (Damsyik, Beirut: Dār al-Qalam, 1412H), 562-563. See also: 
والملاحظ في السياق القرآني أن مصدر الموضوعية وهو الفعل

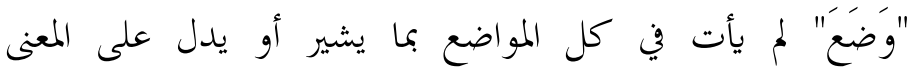

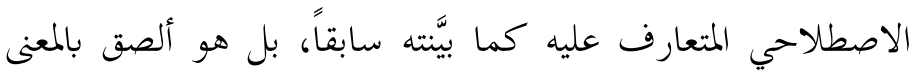

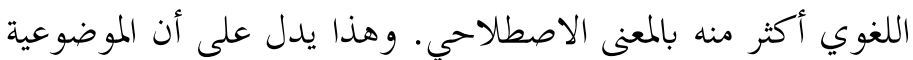
تختلف في الاستعمال القرآني عنه في مناهج البحث العلمي وفي العلوم الاجتماعية والإنسانية المعاصرة.

ولم يرد مصطلح "الموضوعية" هذا الاسم لا في القرآن الكريم

ولا في السنة النبوية ولا في كتابات مؤرخي تاريخ الأديان من لمرديه علماء المسلمين المتقدمين؛ لأنه مصطلح حادث، "وقد ارتبط

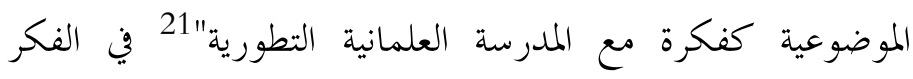
الغربي، فالموضوعية مصطلح غربي ينبثق من الرؤية الخاصة للفكر فيهر الغربي مثله مثل بقية المصطلحات الحادثة في العلوم الاجتماعية

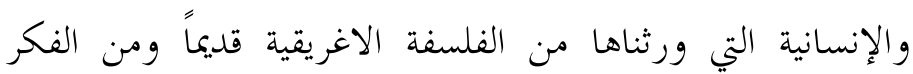

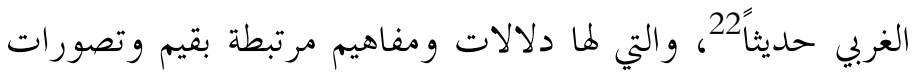

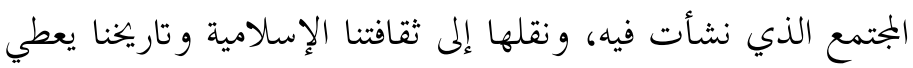

Muhammad Maḥmūd Hijāzì, al-Wahdah al-Mawdī 'iyyah fí alQur'ān, (Cairo: Maṭba 'ah al-Madani, 1390H/1970), 33.

${ }^{21}$ Al-Salmī, Manhaj Kitābah al-Tārìkh al-Islāmī, 135-136.

22 See: Khalīl Muhammad Rashād, al-Manhaj al-Islāmì li Dirāsah alTārīkh wa Tafsìruhu, ed. 1 (Cairo: Dār al-Manār, 1404H/1984), 3637. 
Abdullah Ahmed, "Objectivity in Religious Study," Afkār Vol. 20 Issue 1 (2018): 229-284

أحكاماً مضللة. والباحث ينبغي له أن يسمي الأشياء بمسمياتا الحقيقية، وأن يحكم عليها حسب الميزان الشرعي 23. وإذا قمنا باستقراء منهجية القرآن الكريم في دراسة الأديان

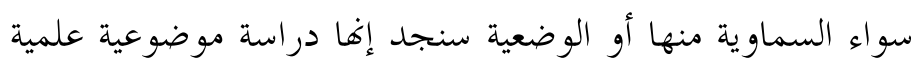
مستقلة في مفهومها ومعاييرها ور كائزها عن الموضوعية في العلوم

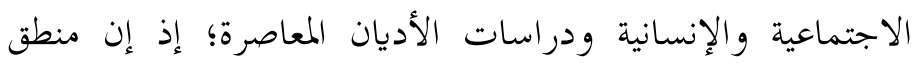

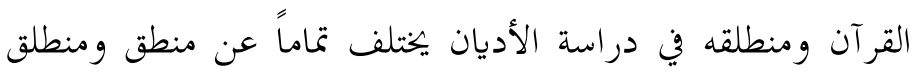

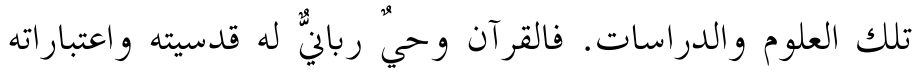

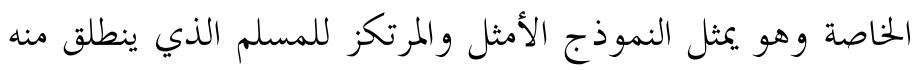

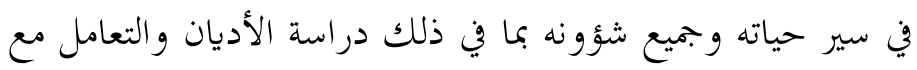

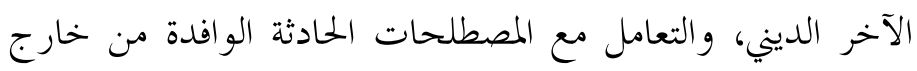
الثقافة والفكر الإسلامي.

المبحث الثاني: الموضوعية في دراسة الأديان في القر آن الكريم

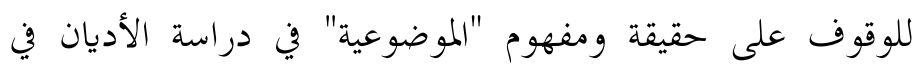

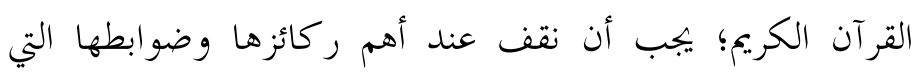
تحدد مفهومها، وتضبط معانيها، وتوضح حقيقتها. المطلب الأول: ركائز الموضوعية في دراسة الأديان

${ }^{23}$ Mas'ūd Jamāl 'Abd al-Hādī, Jum'ah Wafā Muhammad Rafa'at, Manhaj Kitābah al-Tārikh al-Islāmì Limādhā? Wa Kayf? ed. 3 (alManșūrah: Dār al-Wafā, 1414H/1994), 230. 
Abdullah Ahmed, "Objectivity in Religious Study," Afkār Vol. 20 Issue 1

تقف "الموضوعية" في دراسة الأديان في المصطلح القرآني، على أربع ركائز رئيسة، وهي:

الركيزة الأولى: العدل والإنصاف: لقد أمر الله تعالى بالعدل

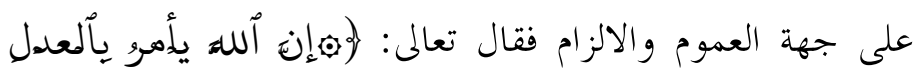

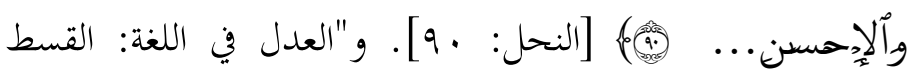
والإنصاف، وعدم الجور. وأصله التوسط بين المرتبتين؛ أي: الإفراط

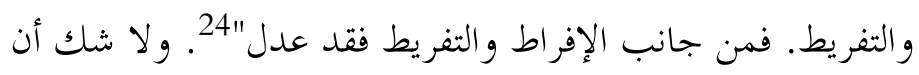
التعامل مع الموافق أو المخالف، ومع الأفكار والمعلومات والأشخاص والجماعات والأمم والأديان يجب أن يكون بعدل وإنصاف، وتوسط واعتدال دون إفراط أو تفريط. ولأهمية العدل

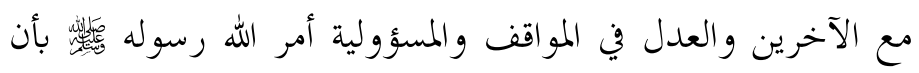

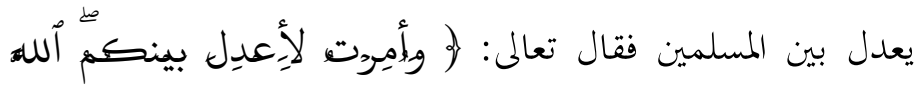

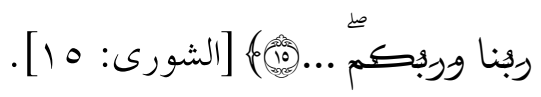

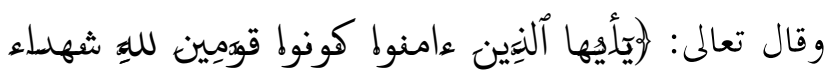

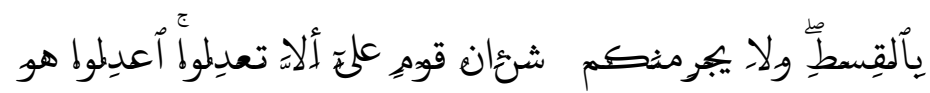

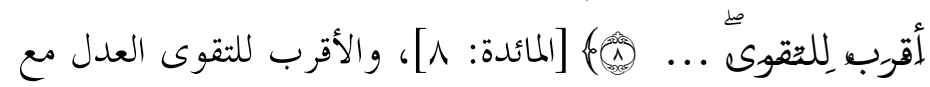
المخالفين لنا في الدين والمعتقد والرأي ووجهات النظر وأن لا يحملنا

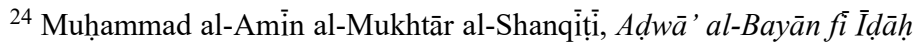
al-Qur'ān bi al-Qur'ān, vol. 2 (Beirut: Dār al-Fikr, 1415H/1995), 437; Muḥammad ibn Jarīr al-Ṭabari, Jāmi ‘ al-Bayān fí al-Ta'wīl alQur'ān, ed. Aḥmad Muḥammad Shākir, ed. 1, vol. 17 (Beirut: Mu'assasah al-Risālah, 1420H/2000), 279. 
بغض قوم لنا على ترك العدل فيهم، بل نستعمل العدل مع كل

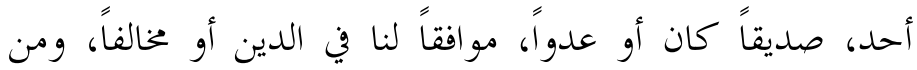

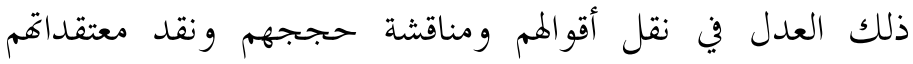
ودراسة أدياهم والحكم عليهم وفي الجدال معظم، وأن لا تأخذنا

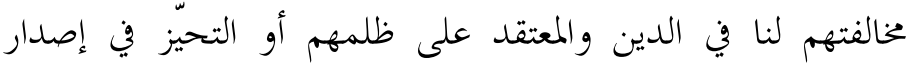

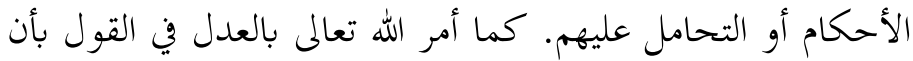
لا نتلفظ إلا بقول الحق والصدق مع الآخرين والأمانة في النقل

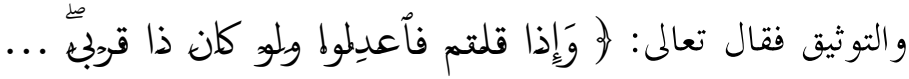

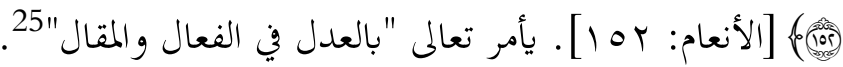
وأمر كذلك بالعدل في إصدار الأحكام على الآخرين فقال تعالى:

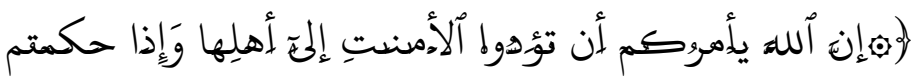

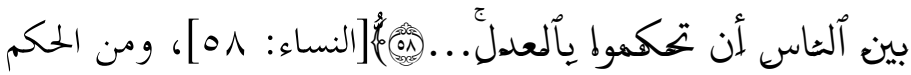

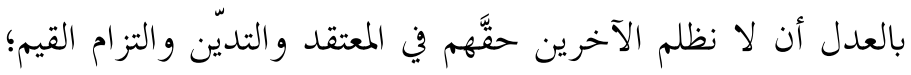
"الأن من أعظم الأشياء عند الإنسان هي معتقداته وقيمه، وينبغي

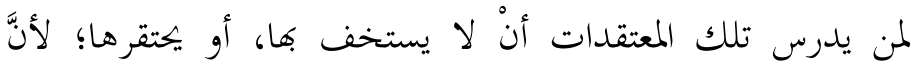
عقائد الناس لها مكانة في قلوب أتباعها تضاهي تلك المكانة التي في

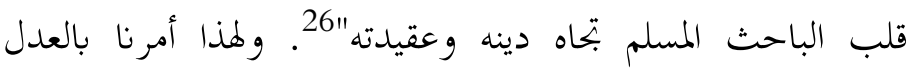

${ }^{25}$ Abū Fidā' Ismā‘īl ibn 'Umar ibn Kathïr, Tafsīr al-Qur'ān al-'Ażim, ed. Sāmí ibn Muhammad Salāmah, ed. 2, vol. 3 (Riyadh: Dār Țayyibah, 1420H/1999), 365.

26 'Umar al-Hāfí, "al-Mawḍ̄’iyyah fỉ Dirāsah al-Adyān”, Islāmiyah alMa'rifah, 15, No. 60, 140. 
Abdullah Ahmed, "Objectivity in Religious Study," Afkār Vol. 20 Issue 1

والانصاف في التعامل مع المخالفين لنا في الدين من اليهود

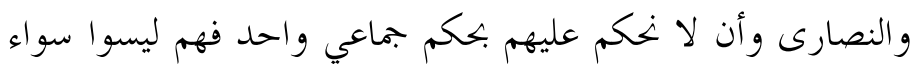

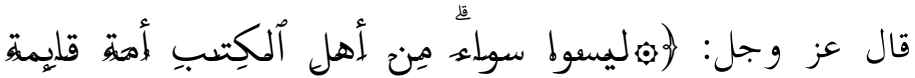

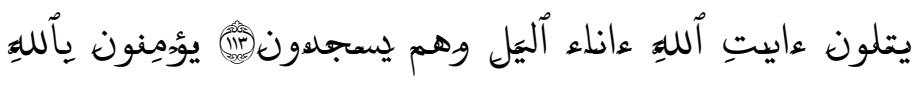

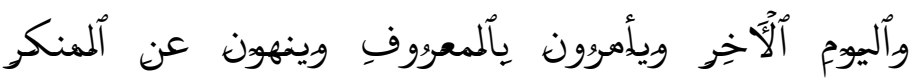

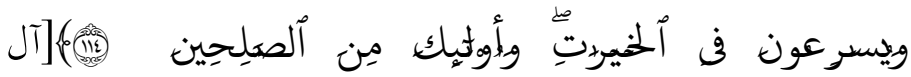
عمران:113-114] والموضوعية القرآنية تعني التزام جانب العدل والانصاف في

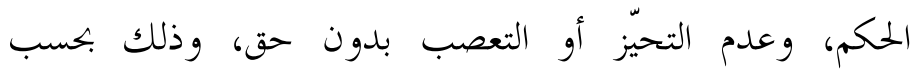

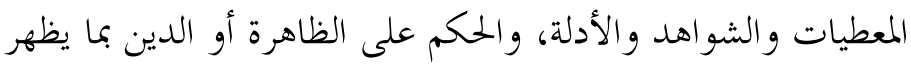
لك من حالها، ومن ذلك إصدار الأحكام القيمية على الأديان

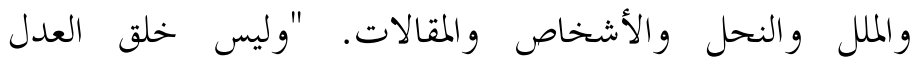

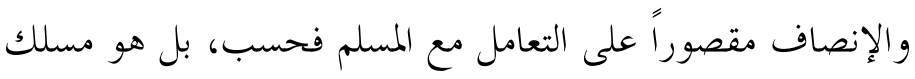
عام، وطابع لازم يجب أن يطبع شخصية المسلم في تعاملاته كلها،

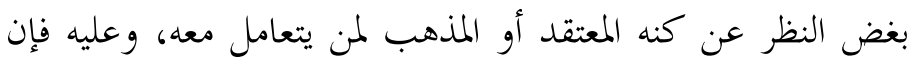
العدل والإنصاف واجب مع الموافق والمخالف، ومع المسلم و اليهودي، و النصراني، و المشرك، ومع صاحب أي دين أو نحلة"27.

${ }^{27}$ Șulțān ibn 'Abd al-Raḥmān al-'Umairì, Șinā'ah al-Tafkìr al-'Aqdī, ed. 1 (London: Takwin li al-Dirasat wa al-Abhath, 1435H/2014), 102. 
Abdullah Ahmed, "Objectivity in Religious Study," Afkār Vol. 20 Issue 1 (2018): 229-284

الثانية: الثئُبْت والثبينُ: وعدم التعجّل في الاثبات والنفي

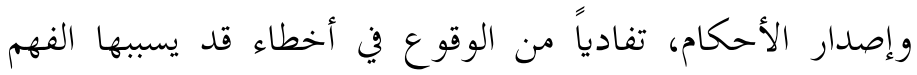

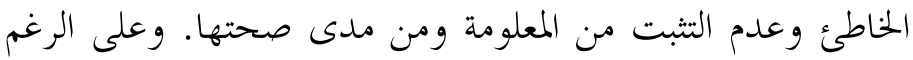

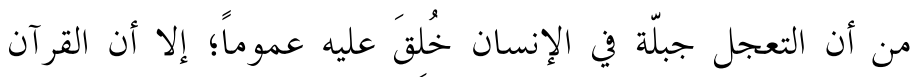

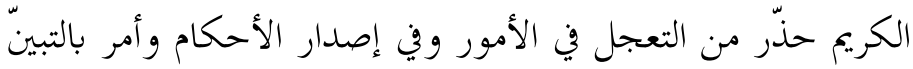

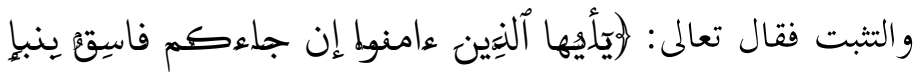

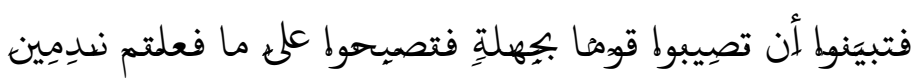

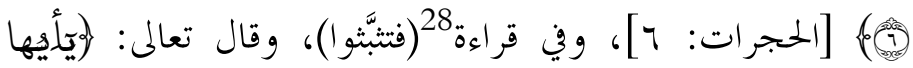

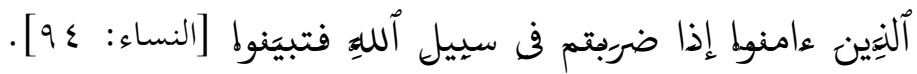

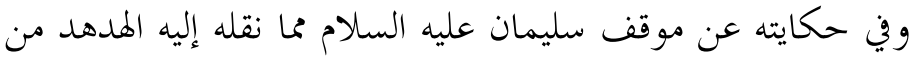

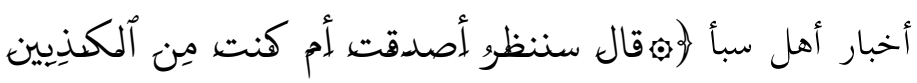

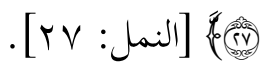

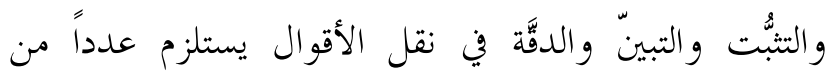

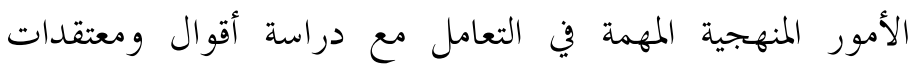

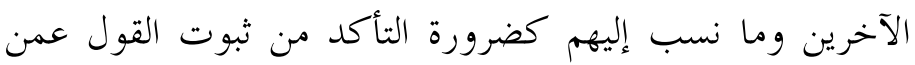

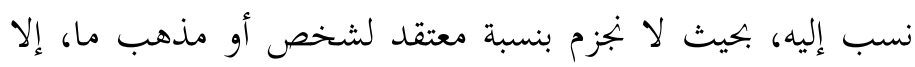
إذا تأكدنا من صدور القول عنه بطريق معتبر، وضرورة نقل الكبل الكلام كما صدر عن صاحبه، دون زيادة أو نقصان، أو تحريف أو تحميله

28 That is reading method of Hamzah and al-Kasā' $\overline{\mathrm{i}}$, see: al-Ṭabari, Jāmi' al-Bayān, vol. 22, 286. 
Abdullah Ahmed, "Objectivity in Religious Study," Afkār Vol. 20 Issue 1 (2018): 229-284

ما لا يحتمل، ويقتضي ذلك نقله حرفيًَا وليس بالمعنى، ولا سيما أن

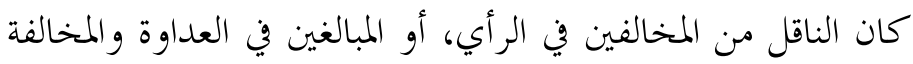

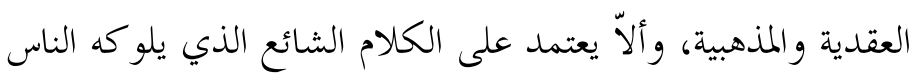

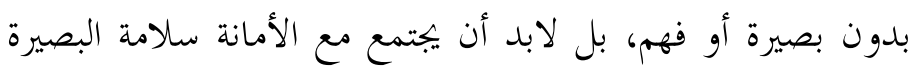

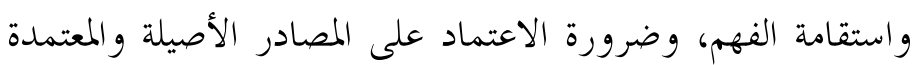

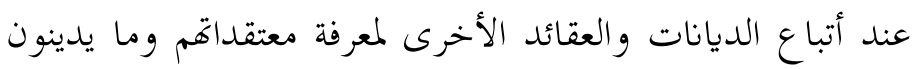

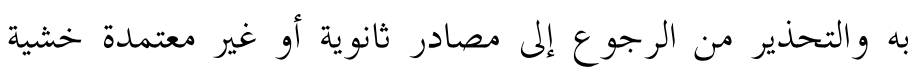
الوقوع في الحكم الجائر والخاطئ والقول بلا علم مُ2.

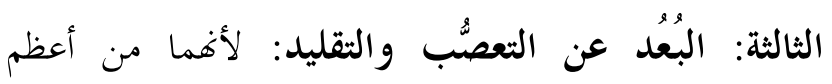

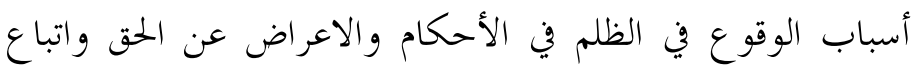

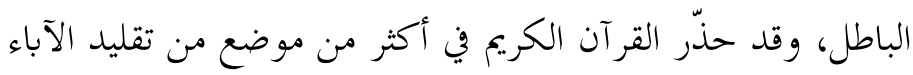

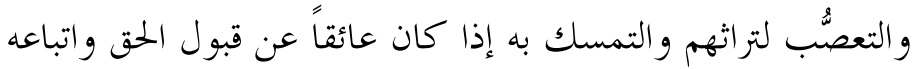

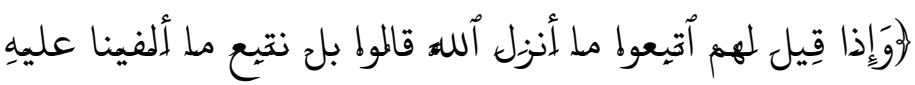

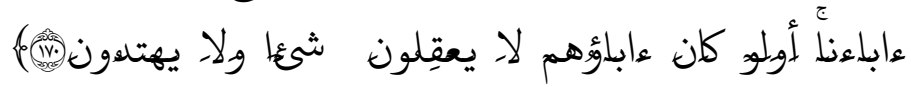

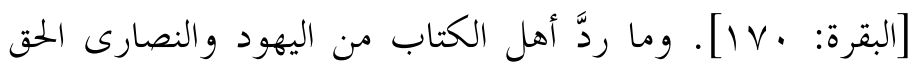

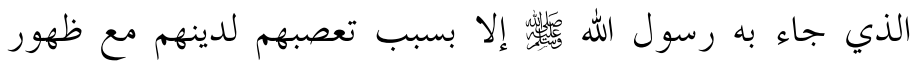
آيات نبوته ورسالته ومعرفتهم بصدق دعوته. ولا يقتصر التقليد

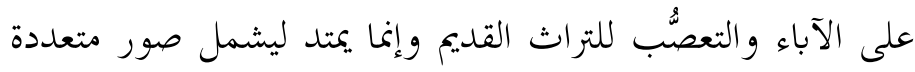

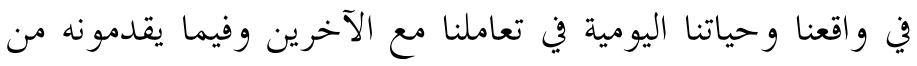

${ }^{29}$ See: al-'Umairī, Șinā’ah al-Tafkir, 42-44. 
Abdullah Ahmed, "Objectivity in Religious Study," Afkār Vol. 20 Issue 1 (2018): 229-284

معارف وثقافات وأفكار، فنسارع إلى ردها ورفضها وعدم القبول

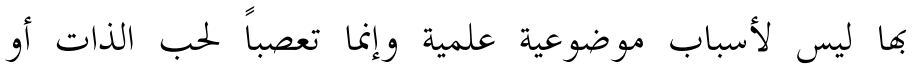

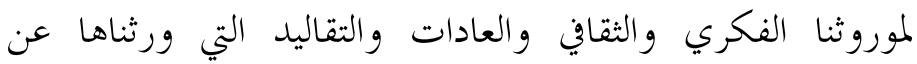
الأسلاف، وربما لمذهب أو فكر أو معتقد نشأنا عليه دون أن نعطيه حقه من التفكر و النظر والتقويم.

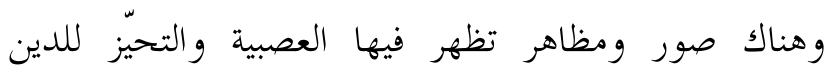
والمعتقد؛ منها تمجيد ما عليه الإنسان من دين ومعتقد وتسفيه واستخفاف لدين ومعتقد الآخرين، كما قال تعالى في حق اليهود

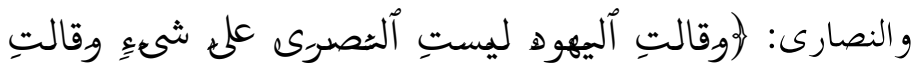

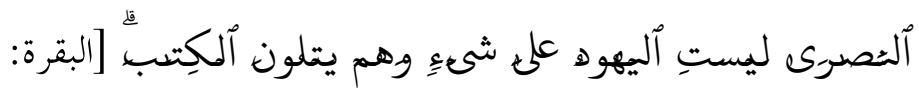

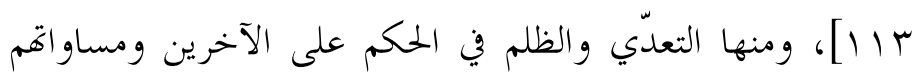

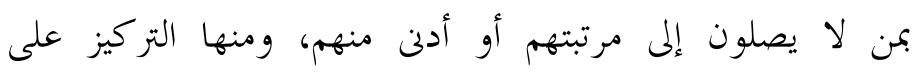
الأخطاء والمساوئ وكتمان الخير والحق عند الآخرين المخالفين

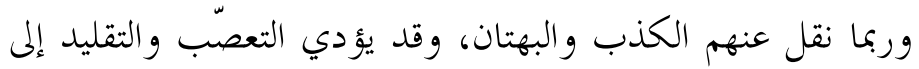

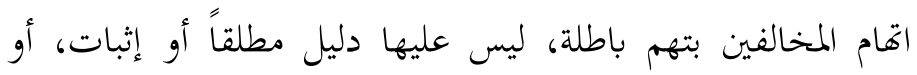

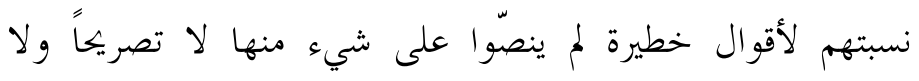
تلميحاً.

الرابعة: التوسط والبُعد عن الغلو: في النظر والحكم على

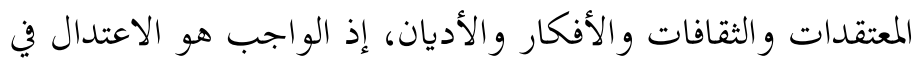

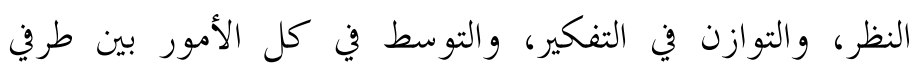


الإفراط و التفريط، والبعد عن الغلو، وخير الأمور أوساطها. ولهذا هى الله عز وجل أهل الكتاب عن الغلو في دينهم فقال تعالى:

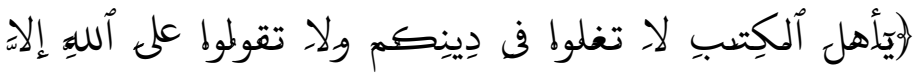

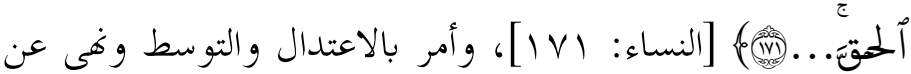

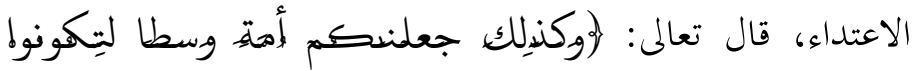

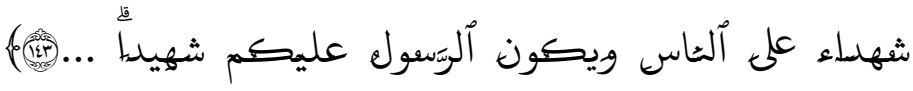

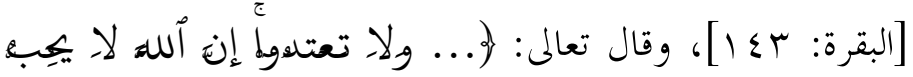

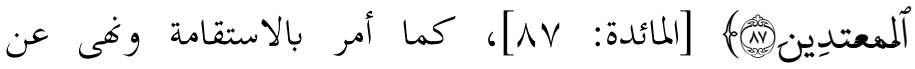
الطغيان، قال تعالى:(فأستقِيم كما أمِرتت ومن تاب معك ولاح

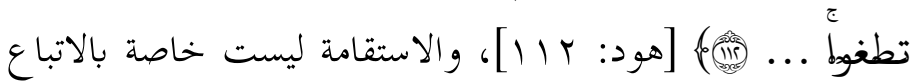
والسلوك بل هي عامة يدخل فيها الاستقامة في النظر في الأقوال

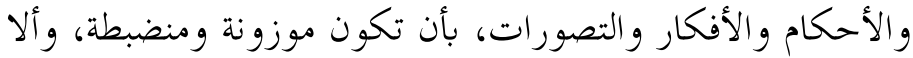
تطغى عند حد الاعتدال والتوسط. و الغلو والتطرف في الأفكار والمعتقدات والآراء خطره عظيم إذ يخرجها عن صواجها وتحول "دون فهم الإنسان لحقائق دينه،

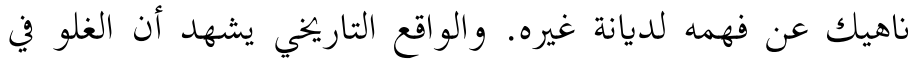

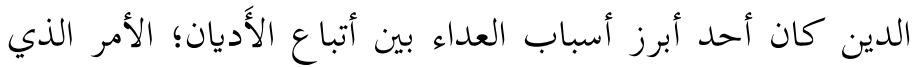
يحول دون قبول الآخر أو احترامه، ناهيك عن فهمه وإنصافه"

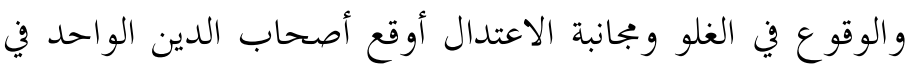

${ }^{30}$ Al-Hāễi, "al-Mawḍū'iyyah fī Dirāsah al-Adyān”, 6. 
Abdullah Ahmed, "Objectivity in Religious Study," Afkār Vol. 20 Issue 1 (2018): 229-284

مزالق ومهالك خطيرة، وأشد منها بين أصحاب الأديان المختلفة

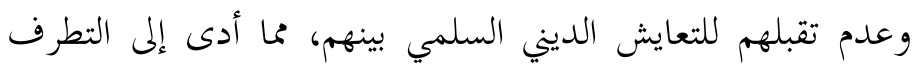
وقيام حروب طويلة بينهم تحت شعار ات وأسماء دينية مقدَّسة.

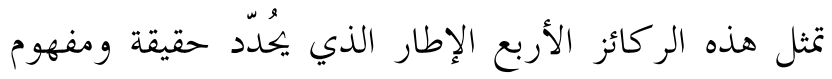

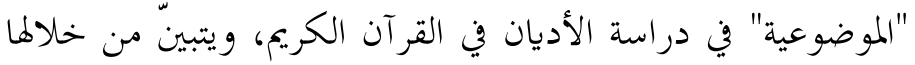

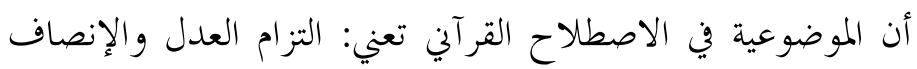

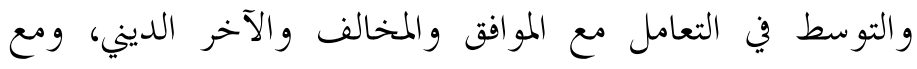

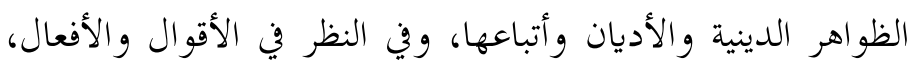

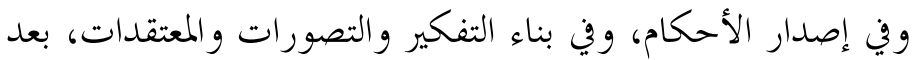

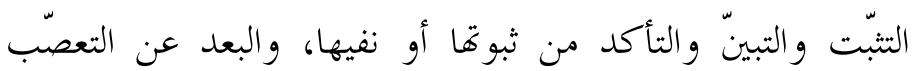

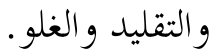

وبهذا المفهوم للموضوعية القرآية يتجلى لنا بوضوح منهجية

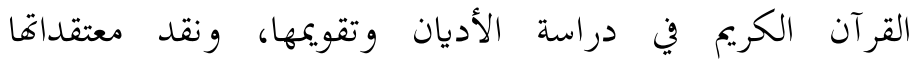

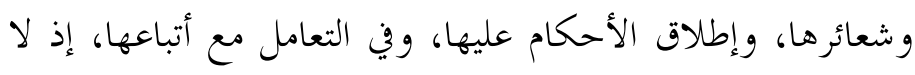

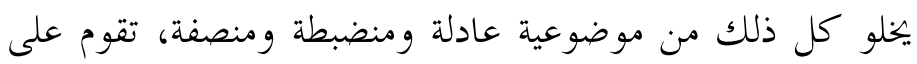

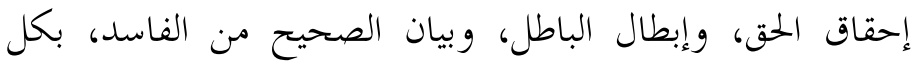
وضوح وعلمية، دون لبس ولا غموض، ووفق معايير وضوابط شرعية تضبط تلك الموضوعية وتحد من التعدي والالتفاف عليها. المطلب الثاني: الضوابط الشرعية للدراسة الموضوعية للأديان 
Abdullah Ahmed, "Objectivity in Religious Study," Afkār Vol. 20 Issue 1 (2018): 229-284

تقوم الموضوعية في دراسة الأديان في القرآن الكريم على ضوابط

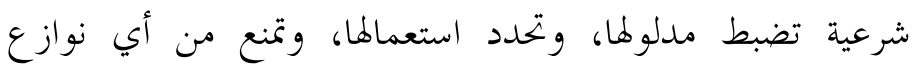

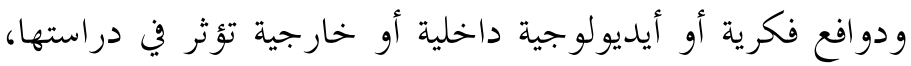
وتلك الضو ابط هي:

الأول: الأمانة: بمفهومها الواسع والشامل، سواء الأمانة العلمية في

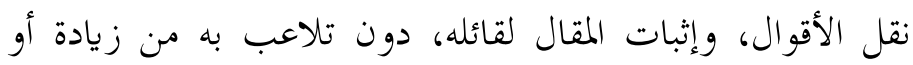
نقصان، أو تغيير وتحريف لمضمونه ومقصده، والأمانة في المحاسبة

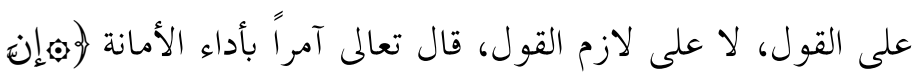

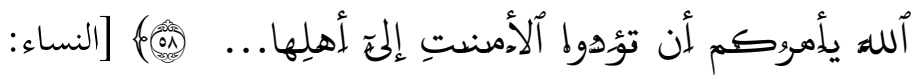
. $[0 \wedge$ وفي المقابل حذّر وفى عن الخيانة، قال تعالى: (لئلئيها ألِّين

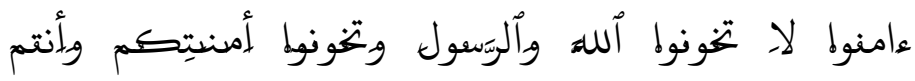

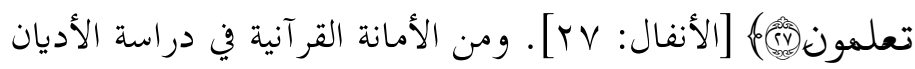

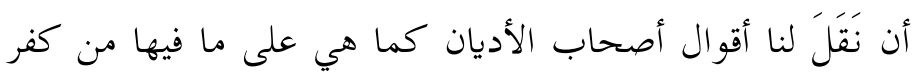
وتعدي على الذات الإلهية كوصفه بالفقر والبخل، كما نقل عقائد

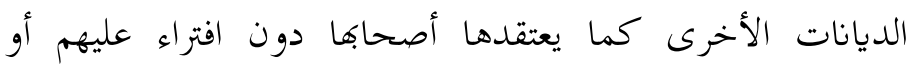
تحريف لحقيقة معتقدهم، كنقله لعقائد النصارى في المسيح عليه

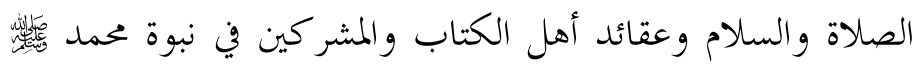

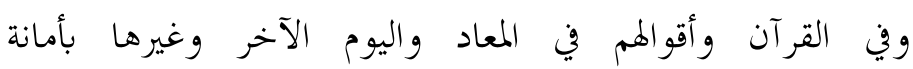


Abdullah Ahmed, "Objectivity in Religious Study," Afkār Vol. 20 Issue 1 (2018): 229-284

وموضوعية، إذ نقل المعارف والأقوال كما هي مع نسبتها لقائليها

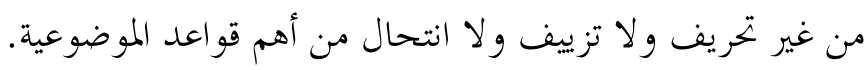

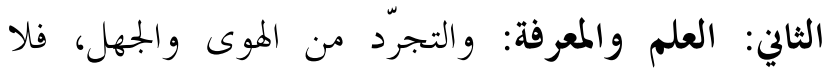

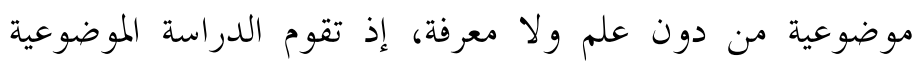

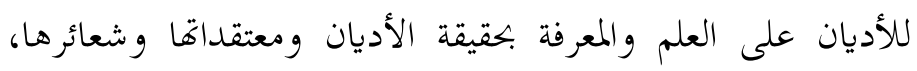

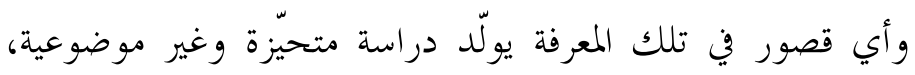

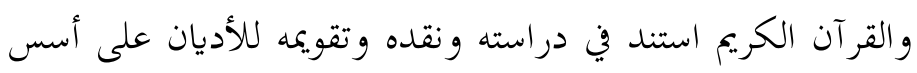
علمية تقوم على الحس والعقل والفطرة، ومن هنا ركّز القرآن

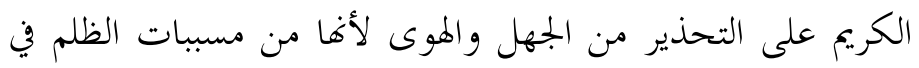

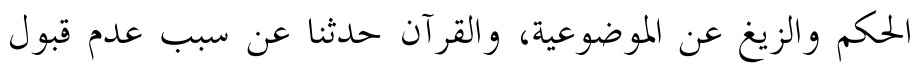

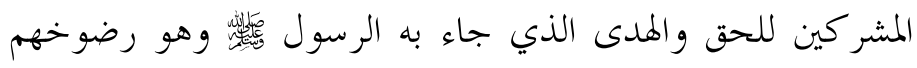

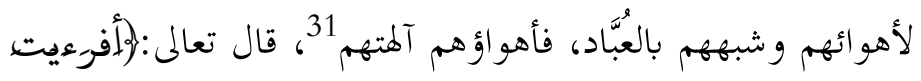

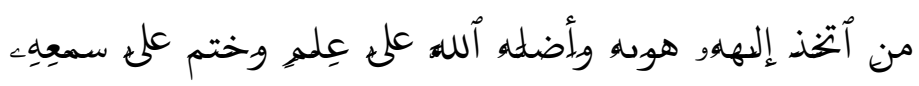

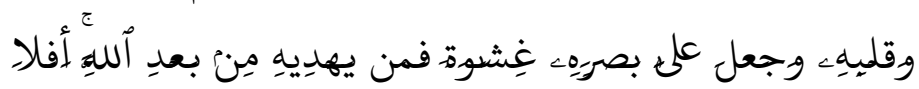

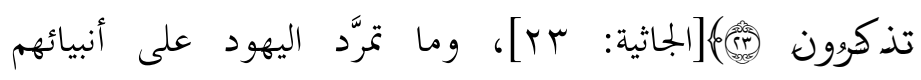

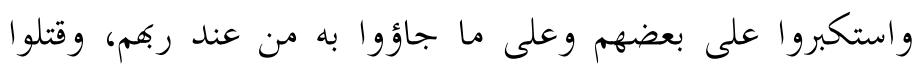

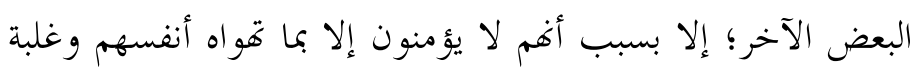

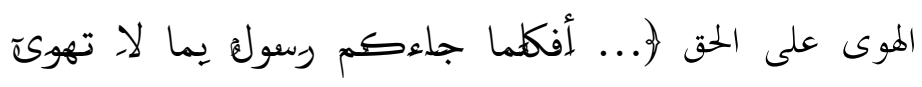

31 'Abd al-Karìm Bakr, Fușūl fì al-Tafkìr al-Mawdū 'ì, ed. 5 (Damascus: Dār al-Qalam, 1429H/2008), 68. 


\section{أنفسطم أستكمبرقم ففريقا كذبتمع وفريقا تقتلون} [البقرة: AV]؛ ولمذا حذّر الله أنبياءه من اتباع الهوى فقال تعالى

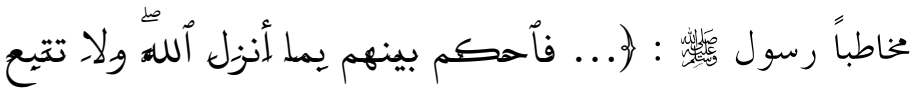

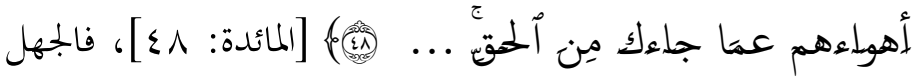

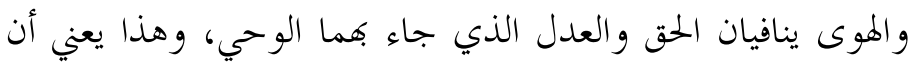

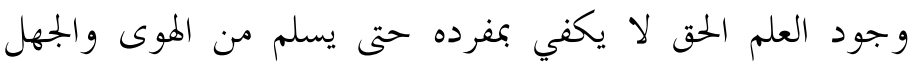

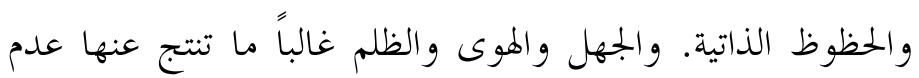

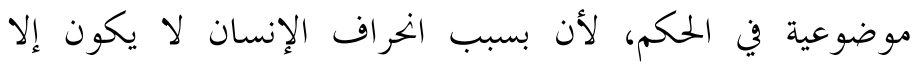

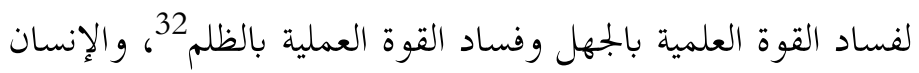

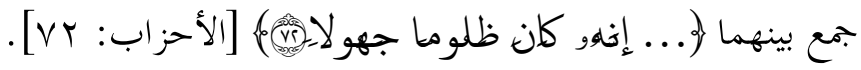

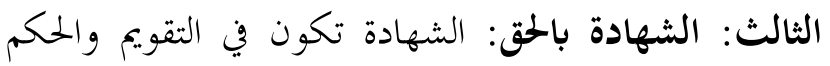

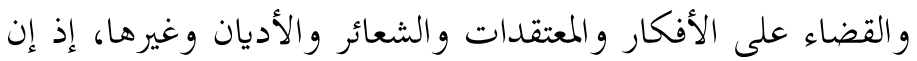

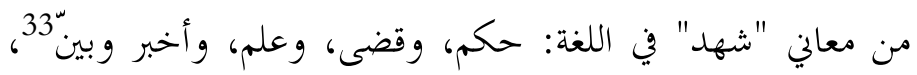

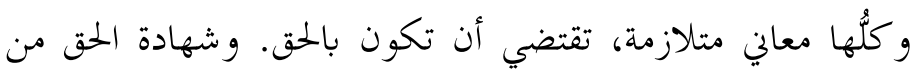

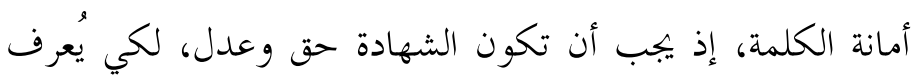

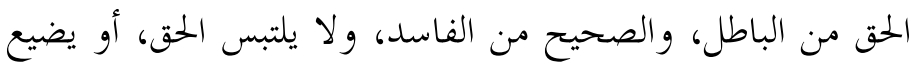

${ }^{32}$ Muḥammad ibn Basīs al-Sufyāni, al-Asas al-Manhajiyyah li naqd alAdyān Dirāsah fí Su'āl al-Manhaj wa Nazariyah al-Bahth, ed. 1, vol. 2 (Jeddah: Markaz al-Ta'ṣill li al-Dirāsāt wa al-Buhūth, 1437H/2016), 746.

${ }^{33}$ See: Muḥammad ibn Ahmad al-Harawi al-Azharì, Tahzỉb al-Lughah, ed. Muhammad Awaḍ Mur'ib, ed. 1, vol. 6 (Beirut: Dār Iḥyā’ alTurāth al-'Arabì, 2001), 47. 
Abdullah Ahmed, "Objectivity in Religious Study," Afkār Vol. 20 Issue 1 (2018): 229-284

أو يخفى على الآخرين. وقد أمر الله تعالى بشهادة الحق وقرغها بالعلم

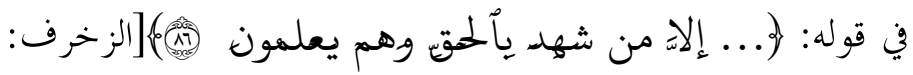
1 1]، و ولا تكون شهادة حق إلا إذا كانت عن علم ومعرفة واعتقاد صحيح والمعيار في معرفة الحق هو الشرع وما جاء به الوحي في

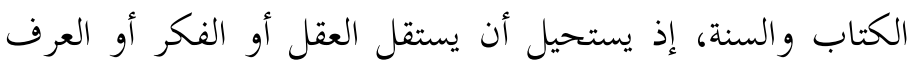

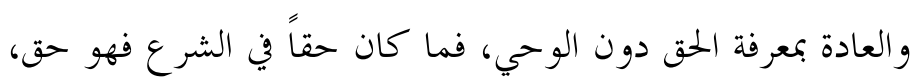

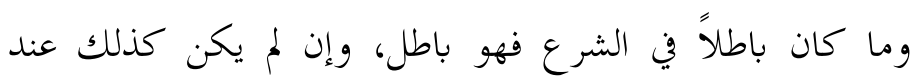

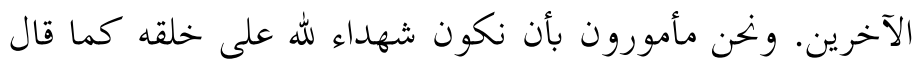

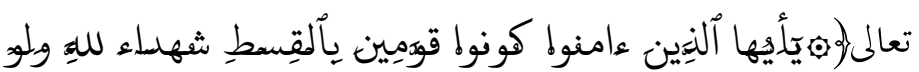

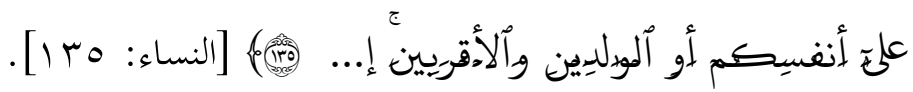
كما فى الله تعالى عن كتمان الشهادة وإخفائها، قال تعالى:

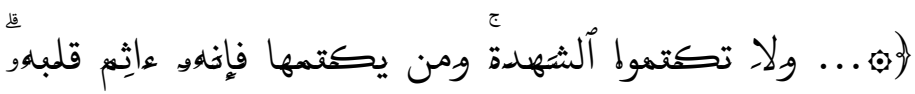

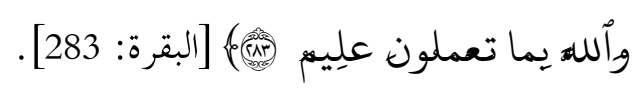

والشهادة بالحق تقتضي أن يكون الباحث والناقد والحاكم لهمبم

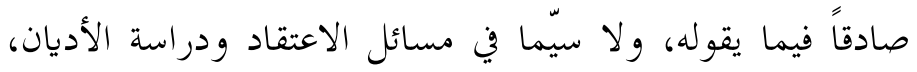

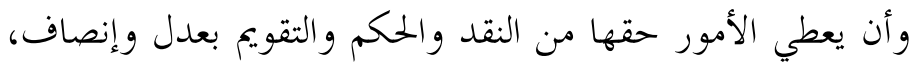

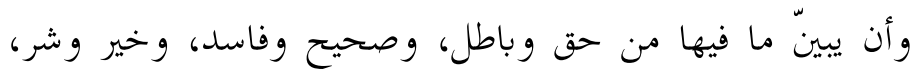

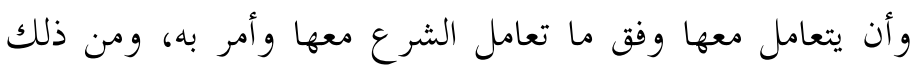

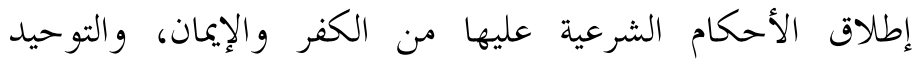


Abdullah Ahmed, "Objectivity in Religious Study," Afkār Vol. 20 Issue 1 (2018): 229-284

والشرك، و الهدى والضلال، و وألاّ نستبدل ذلك بمسميات حادثة

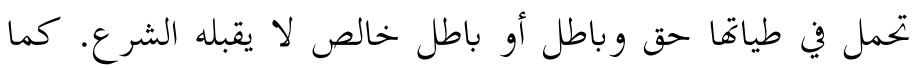
تقتضي الشهادة بالحق وجوب الصدق في الاخبار والبيان، وفي النصح والتوجيه والتقويم عند دراسة الظواهر الدينية، والممارسات

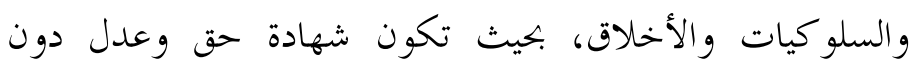

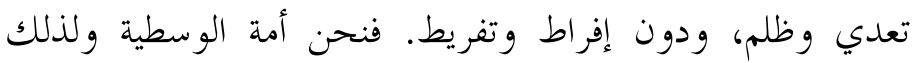
جعلنا الله تعالى شهداء على الناس، ولن نكون شهون ونداء على الناس

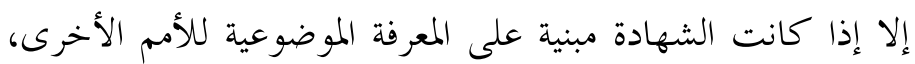

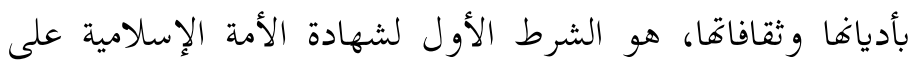

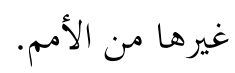
الرابع: البعد عن الظن والتخرّص: كما أمرنا بالثتُبتّ

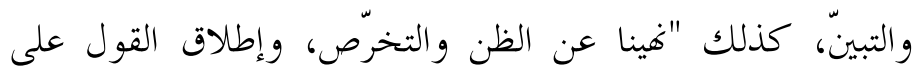

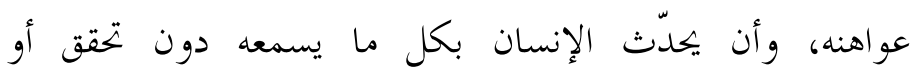

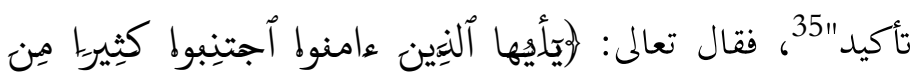

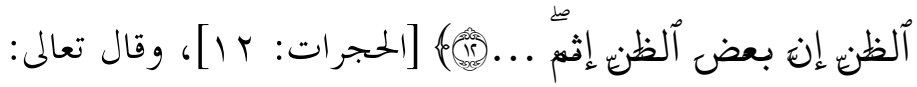

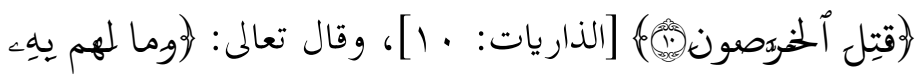

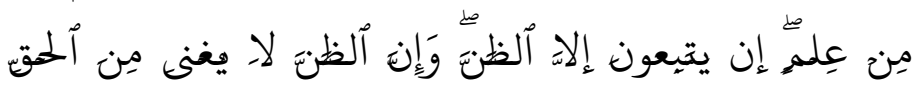

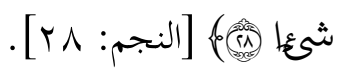

${ }^{35}$ Al-'Umairì, Șinā' ah al-Tafkir, 41. 
Abdullah Ahmed, "Objectivity in Religious Study," Afkār Vol. 20 Issue 1 (2018): 229-284

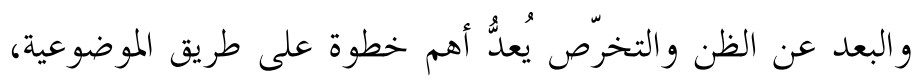

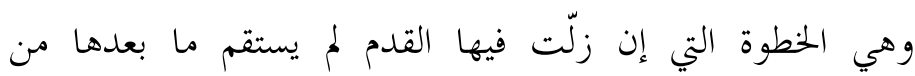

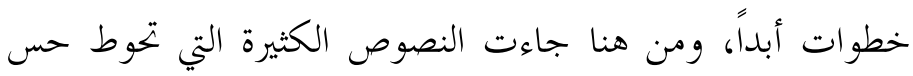

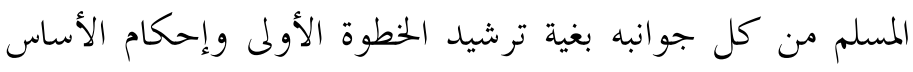

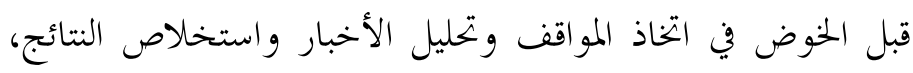
و "قرر القرآن في مواضع عدة عدم صلاحية الظنون في بناء

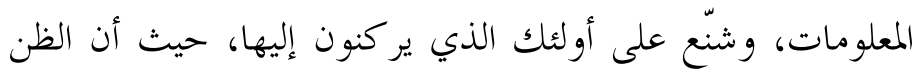

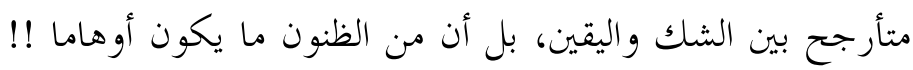

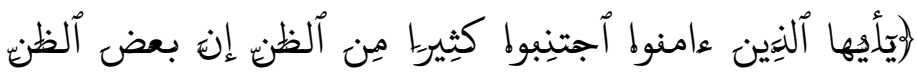

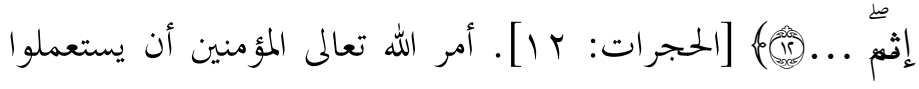

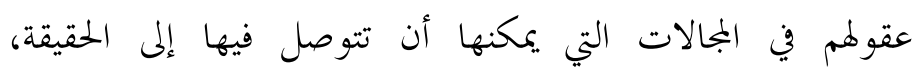

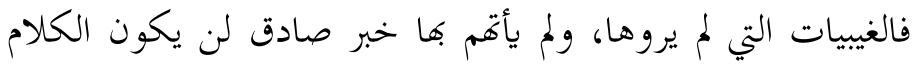
فيها أكثر من اللغو والعبث، ولن يكون أكثر من الأوهام والظنون.

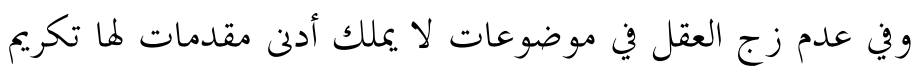
له، كما أن في ذلك حفظا للمنهج من أن يخرج عن عن الإطار العلمي

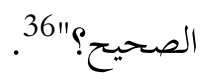

الخامس: الجمادلة بالتي هي أحسن: في بيان الحق ونصرته،

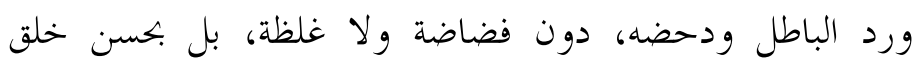
ولطف ولين كلام، وأدب في الحوار والمناقشة وعرض ورد ونقد ولد الأفكار

${ }^{36} \mathrm{Bakr}$, Fuṣūl fì al-Tafkìr al-Mawdū 'ì,63. 
والتصورات والمعتقدات. وقد هیى الله تعالى عن مجادلة أهل الكتاب إلا بالتي هي أحسن و"الجميل من القول، وهو الدعاء إلى الله بآياته،

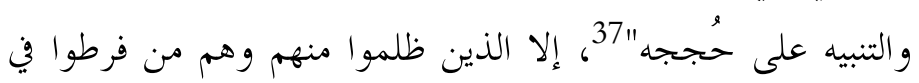

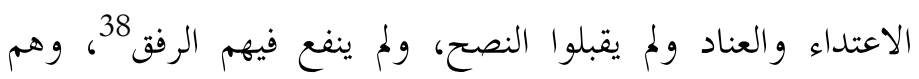

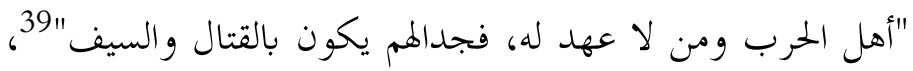

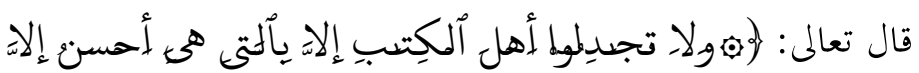

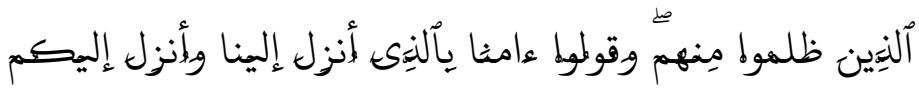

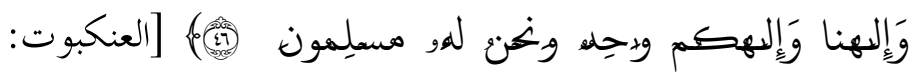

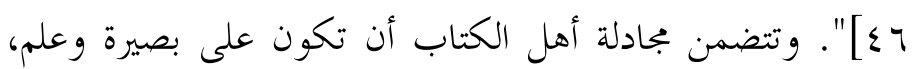
وأن يقصد منها بيان الحق وهداية المجادَل، وأن تكون دعوة إلى الحق وتحسينه، ورداً عن الباطل وتجينه ونان.

\section{المبحث الثالث :إثكاليات في الدراسة الموضوعية للأديان}

تطرح عدد من الإشكاليات حول موضوعية القرآن في دراسته للأديان من قبيل الأحكام القيمية التي أطلقها القرآن الكريم على الأديان وعلى أتباعها كالكفر و الشرك و الضلال، وحصره للحقيقة المطلقة في دين الإسلام دون سائر الأديان، وتحديد الغاية من دراسته

${ }^{37}$ Al-Țabarī, Jāmi` al-Bayān, vol. 20, 46.

38 'Abd al-Majìd ibn 'Abd al-Raḥmān al-Suhaybānī, Kayf Nata'āmal

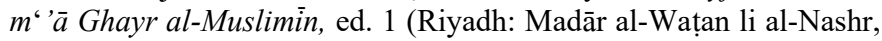
1436H/2015), 109-110.

${ }^{39}$ Al-Ṭabarì, Jāmi' al-Bayān, vol. 20, 46.

${ }^{40}$ Ibid., 109-110. 
Abdullah Ahmed, "Objectivity in Religious Study," Afkār Vol. 20 Issue 1 (2018): 229-284

للأديان هل هي لمجرد المعرفة والتجرد من الأحكام والتحيّز أم لمعرفة

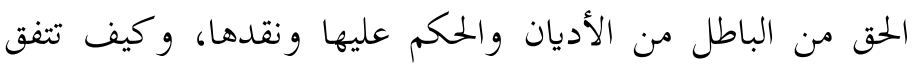
الموضوعية مع النقد والتقويم الذي سار عليه القرآن في دراسته للأديان وحصره للحقيقة المطلقة في دين واحد لا غير. وسنتناول في هذا المبحث تلك الإشكاليات وتوضيح موقف الموضوعية القرآنية منها بإيجاز .

المطلب الأول: الموضوعية وإصدار الأحكام القيمية

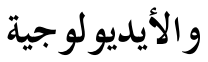

يعتقد البعض أن وظيفة الأديان ليست "أن يهكم بينها، أو يمدّد الصحيح والخاطئ منها، وإن وظيفته تتمثل في العرض المنهجي لما لمان

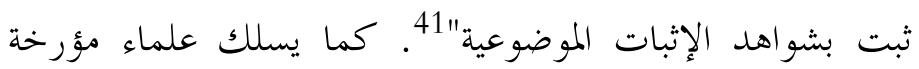
الأديان في الانثروبولوجيا الاجتماعية الذين يؤمنون بدراسة الظاهرة الدينية بوصفها ظاهرة اجتماعية تستحق الدراسة مثل أي ظاهرة أخرى وفق مناهج علم الاجتماع، دون إصدار أحكام قيميّة في

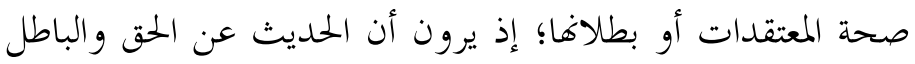

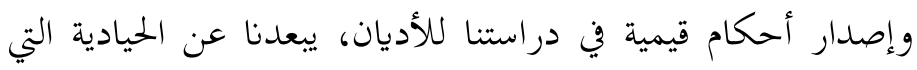
يفرضها علينا البحث العلمي، ومن تم لا فضل لمعتقد دون آخر،

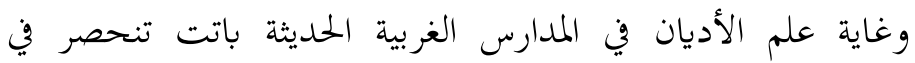

${ }^{41}$ Muhammad al-Hadād, Tajārib Kawniyyah fí Tadrīs al-Adyān, ed.1 (Dubai: Markaz al-Musābar li al-Dirāsāt wa al-Buhūth, 2014), 67. 
Abdullah Ahmed, "Objectivity in Religious Study," Afkār Vol. 20 Issue 1

الوصف والتحليل من خلال مناهج علم الاجتماع، وعلم النفس،

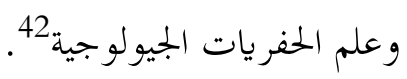

وهذا الاعتقاد والقول القائم على الكف عن لهن "إصدار

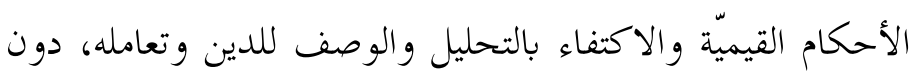
إصدار أحكام قيميّة، يقلل من قيمة هذا العلم وأهميته؛ إذ لا فائدة

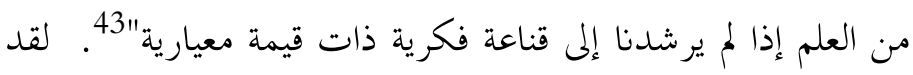

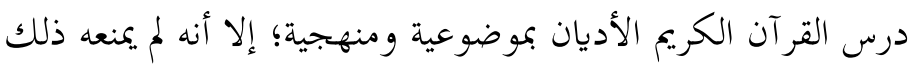

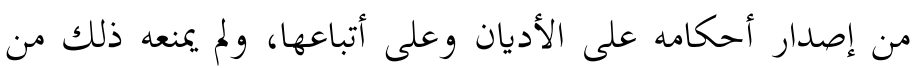

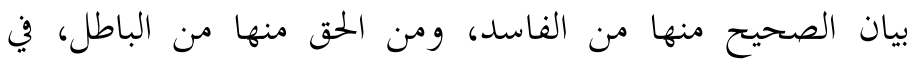

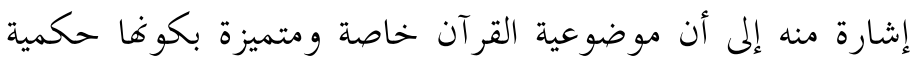

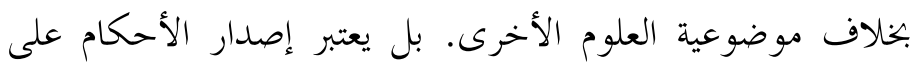

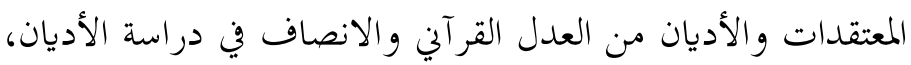

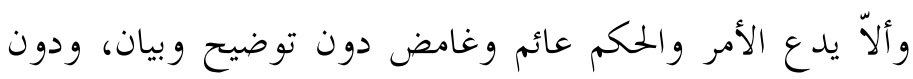

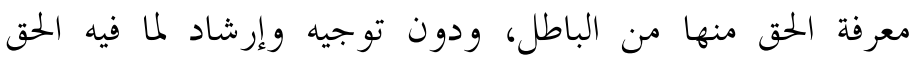
والأمر بالتزامه، وتحذير وغي عما فيه باطل والأمر باجتنابه.

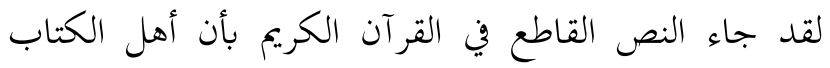

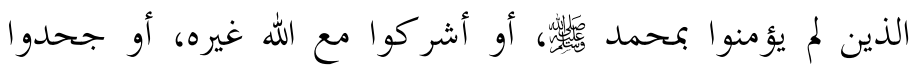

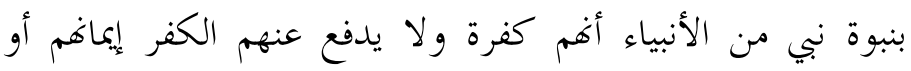

\footnotetext{
42 'Abd al-Razzāq 'Abd Allāh Ḥash, "'Ilm Muqāranah al-Adyān bayn Su'ālì al-Mafhūm wa al-Mawḍ̄'iyyah”, Islämiyah al-Ma'rifah, alSunnah, 17, No. 67, 88 .

${ }^{43}$ Ibid., 88.
} 
Abdullah Ahmed, "Objectivity in Religious Study," Afkār Vol. 20 Issue 1 (2018): 229-284

التزامهم بكتابهم، فلو آمنوا حقاً بالنبي والكتاب لآمنوا بجميع الأنبياء

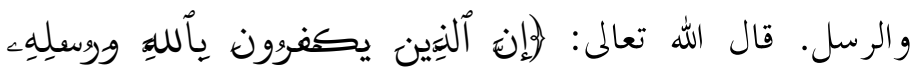

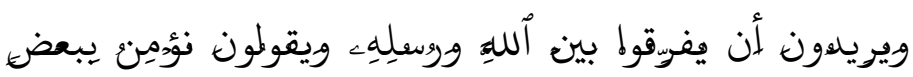

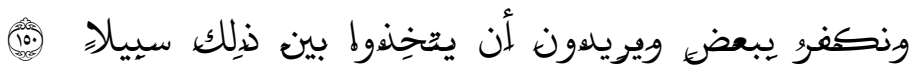

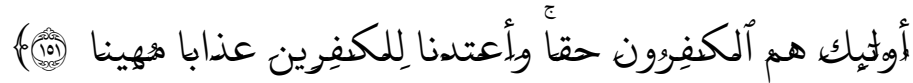

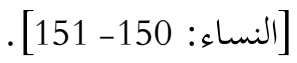

وما جاء في القرآن الكريم من وعد النصارى أو اليهود بالجنة

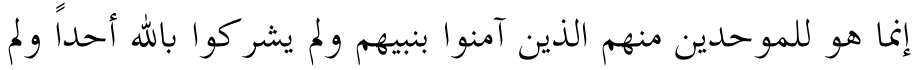
يدر كوا بعثة نبينا محمدئل بكتاب الله عز وجل، ويؤيده أن من اعتقد ألوهية عيسى أو بنوته لله أو أعتقد أن الله فقير أو يمسه اللغوب وجلو والتعب فليس مئ مؤمناً بالله

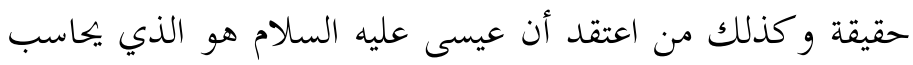

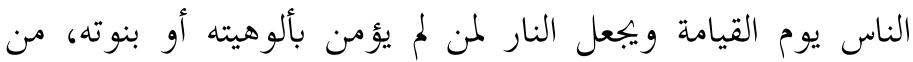

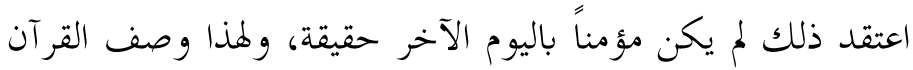

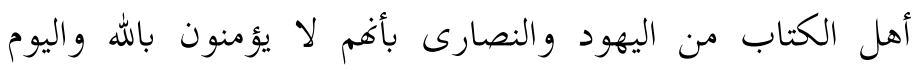
الآخر.

والحكم بكفر أهل الكتاب والمشركين معلوم من الدين بالضرورة، والأمة قاطبة مجمعة عليه ونصوص القرآن في ذلك كثيرة، وجاءت أدلة مستفيضة في التحذير من اتباعهم والتشبَّه بكم

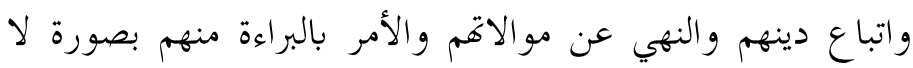


تجعل هناك مجالاً للتشكيك فيها، و لا ينافي هذا المسلك الموضوعية في دراسة الأديان؛ إذ إن ذلك نابع من خصوصية القرآن الموضوعية، ومنهجه وأسلوبه الخاص به في عرض ونقد الأديان، والذي يختلف عن سائر الدراسات المعاصرة. و

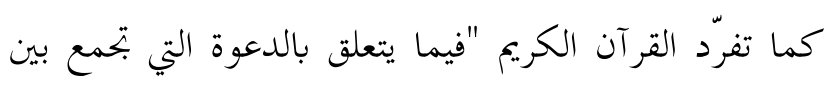

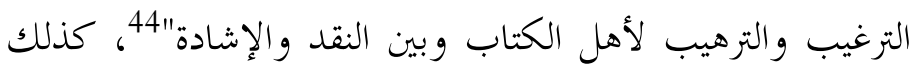

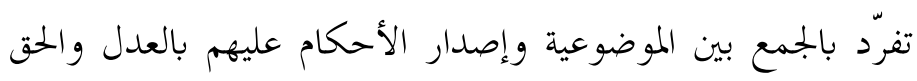
والإنصاف دون جَور ولا ظلم، حيث بيٌّ الحق و الباطل فيها، وكشف حقيقة هذه الأديان وما تقوم عليه من أصول عقدية وتعبدية؛ بكل صدق ووضوح في إصدار الأحكام وعدم المجاملة

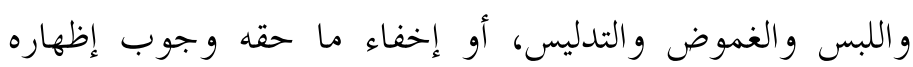
و التصريح والحكم به. إذ إن من مقاصد القر آن الكريم "هداية الناس وله وإرشادهم إلى الطريق الصحيح الموصل إلى الهدف السديد من

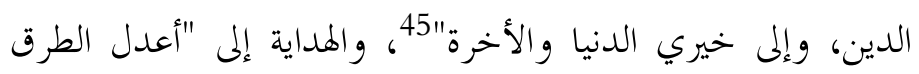

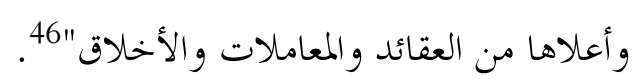

\section{المطلب الثالي: الموضوعية ونسبية الحقيقة الدينية}

44 Aḥmad Șalāḥ al-Buhansî, al-Qur'ān al-Karim wa 'Ulūmuh fí Mawsū 'àt al-Yahūdiyyah, ed. 2 (Riyadh: Markaz Tafsir li al-Dirāsāt al-Qur'āniyyah, 1436H/2015), 227.

45 Wahbah ibn Mustafā al-Zuhayli, al-Tafsìr al-Wasiț, ed. 1 vol. 1 (Damascus: Dār al-Fikr, 1422H), 444.

46 Țāha 'Abidīin, Yāsin Qārî, Fakhr al-Dīn al-Zubayr 'Alì, al-Hidāyāt al-Qur'āniyyah Dirāsah Ta'șiliyyah, ed. 1, vol. 2 (Damām: Maktabah al-Mutanabbi, 1438H/2017), 846. 
تقوم نسبية الحقيقة الدينية على إشكالية: هل الأديان كُلْها على ألى

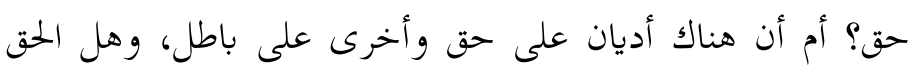

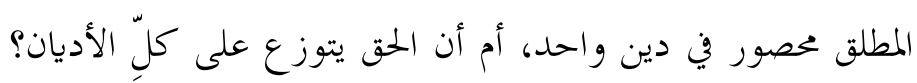

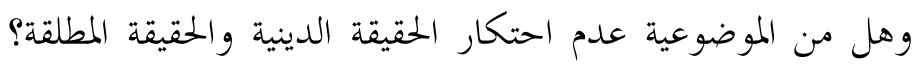

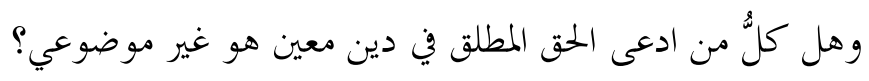

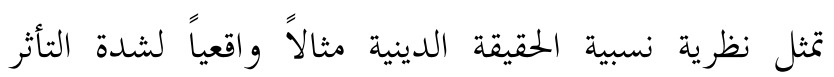
بالفكر الغربي في العلوم الاجتماعية والإنسانية في مصطلحاتها

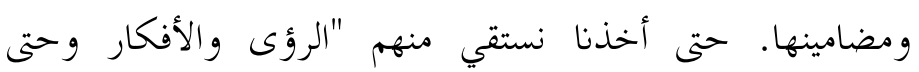

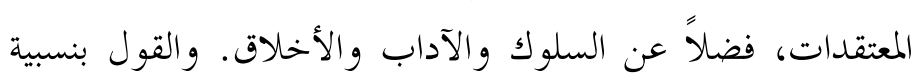

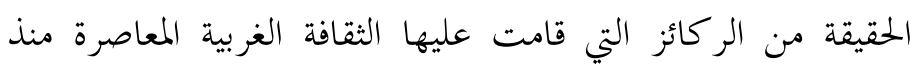

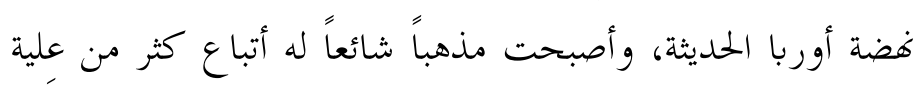

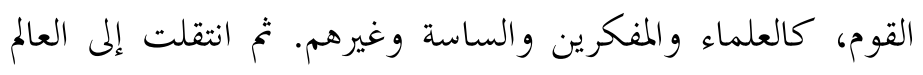

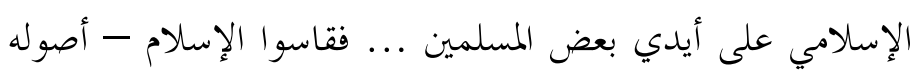
العقدية وقيمه الخلقية- على المذهبيات الغربية الباطلة. وبتحاهلوا

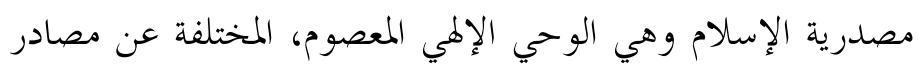

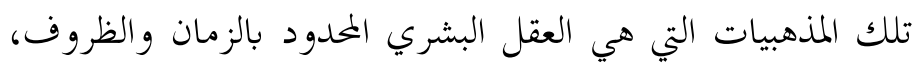
و العرضة للخطل والجهل، ولأهواء و المصالح" و القائلون بنسبية الحقيقة "ليسوا سواء في مقصودهم ولهم للحقيقة،

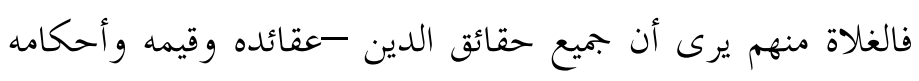

47 'Abd al-Rahmān Zayd al-Zunaydī, al-Salafiyyah wa Qaḍayā al- 'Așr, ed. 1 (Riyadh: Dār Ishbalia li al-Nasyh, 1418H), 79. 
Abdullah Ahmed, "Objectivity in Religious Study," Afkār Vol. 20 Issue 1

وآدابه- نسبية، وبعضهم يرون أن النسبية لبعض أحكام الدين فقط،

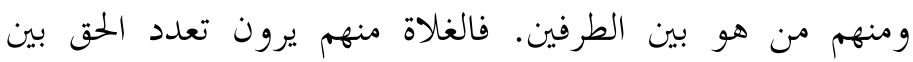

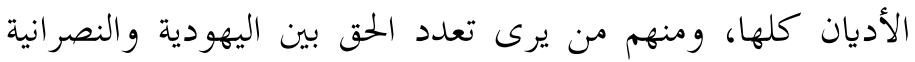

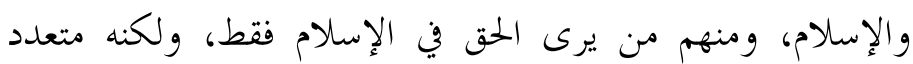

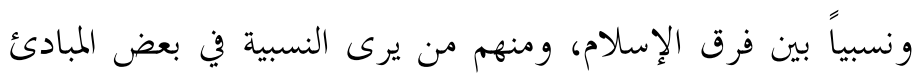
أو بعض الأحكام القطعية" 48.

إن "الحق مطلق ثابت، لا يتعدد ولا يتغير بتغير معرفة الناس الناس

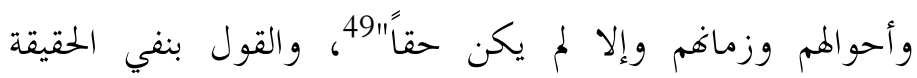

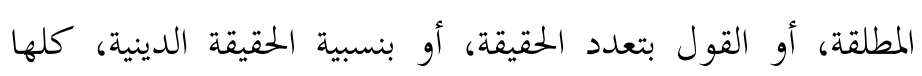

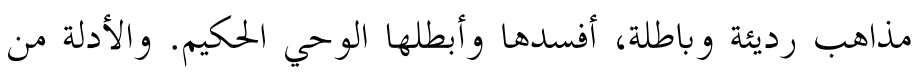

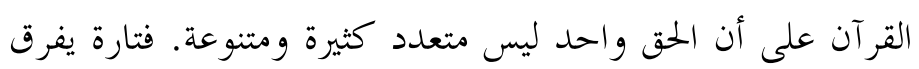

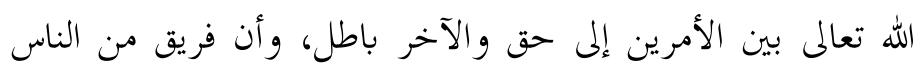

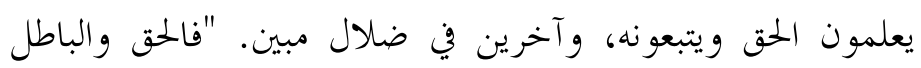

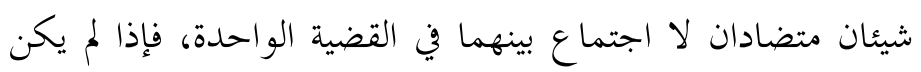

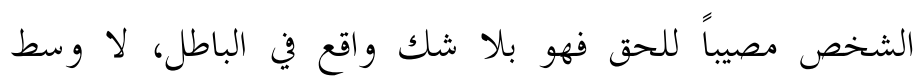
بينهما ولا نسبية في الحق" "50.

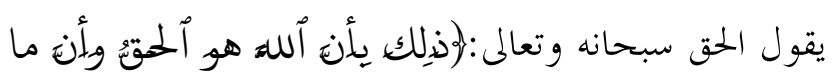

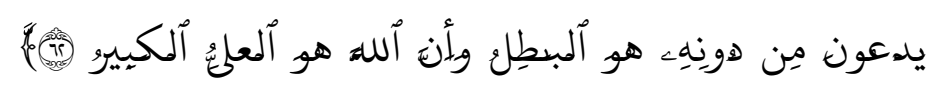

${ }^{48}$ Al-Qaḥ̦ānì, al-Ta'aduddiyyah al-'Aqāidiyyah, 130.

${ }^{49}$ Ibid., 111.

${ }^{50} \mathrm{Ibid} ., 140$. 
Abdullah Ahmed, "Objectivity in Religious Study," Afkār Vol. 20 Issue 1

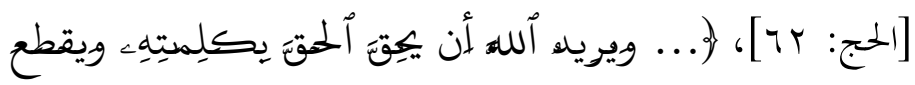

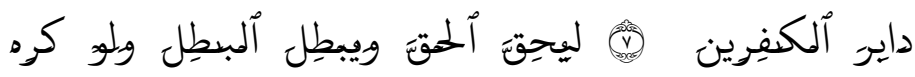

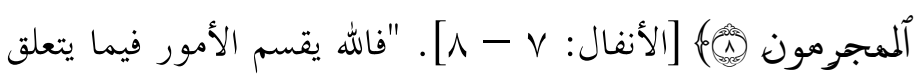

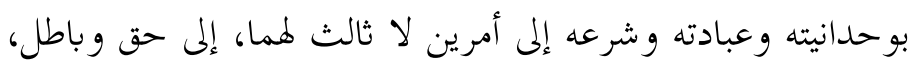
فالله تعالى ودينه حق، وما خالفه باطل، لا كما يقول دعاة نسبية

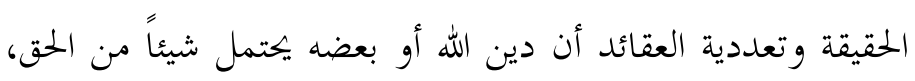

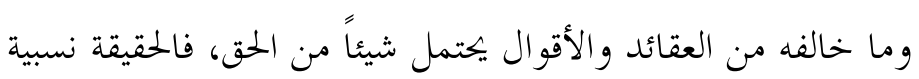

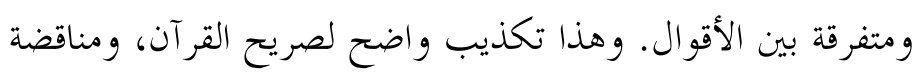

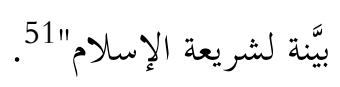

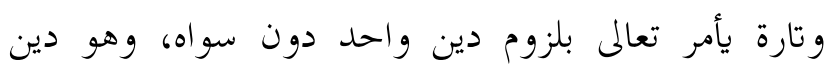

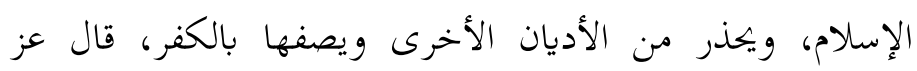

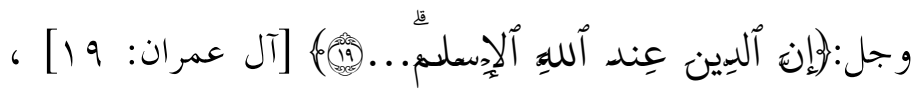

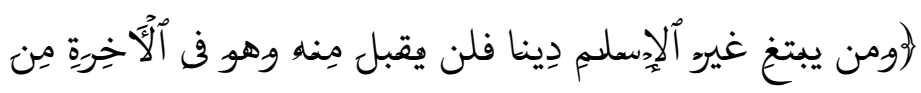

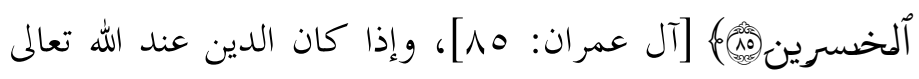

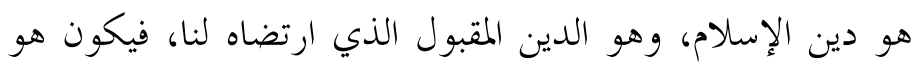

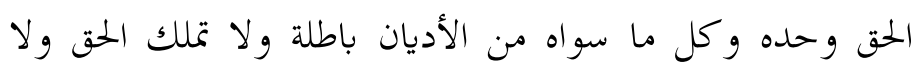

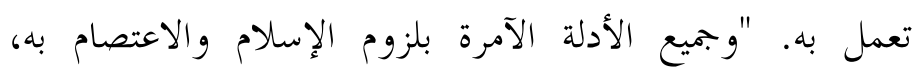

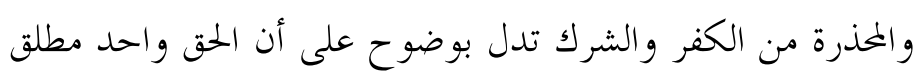

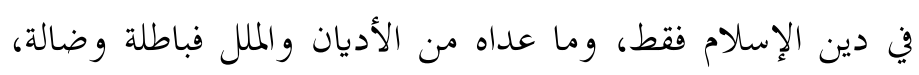

\footnotetext{
${ }^{51}$ Ibid., 142.
} 
Abdullah Ahmed, "Objectivity in Religious Study,” Afkār Vol. 20 Issue 1

وإلا لما فى الله عنها وحذر منها، وحكم على أهلها بالعذاب والنار"

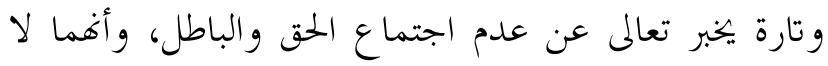

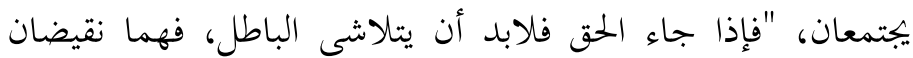

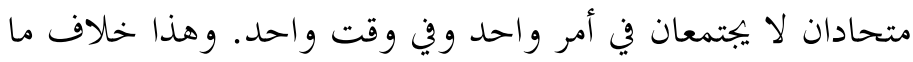

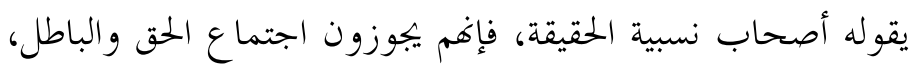

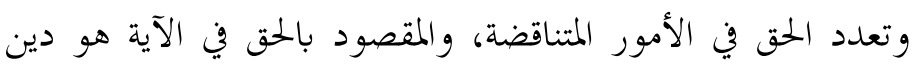

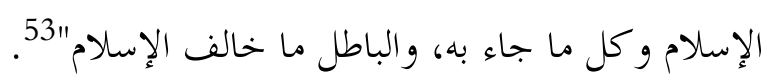

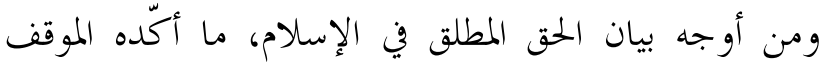

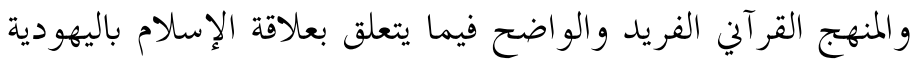

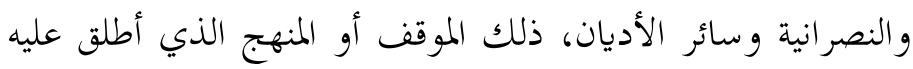

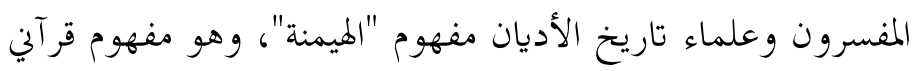

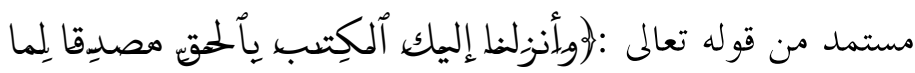

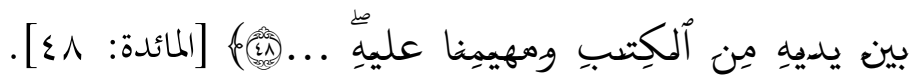
وهو يشير إلى هيمنة الإسلام على الأديان السابقة له "اليهودية

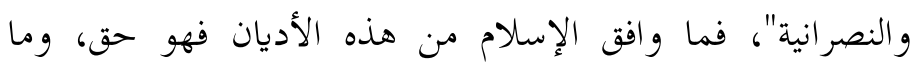
خالفه فهو باطل 54.

${ }^{52}$ Ibid., 146.

${ }_{53}^{53}$ Ibid., 141.

${ }^{54}$ See: Muhammad Khalīah, Tārīkh al-Adyān (Cairo: Dār al-Thaqāfah al-'Arabiyyah, 2002), 254. 
Abdullah Ahmed, "Objectivity in Religious Study," Afkār Vol. 20 Issue 1 (2018): 229-284

والأدلة من القرآن على بطلان مذهب النسبية كثيرة ومستفيضة، و "نفي الحقيقة المطلقة، أو دعوى تعدد الحقيقة ينطوي على تناقض لا يقره العقل؛ إذ يلزم منه أن يكون الشيء الواحد

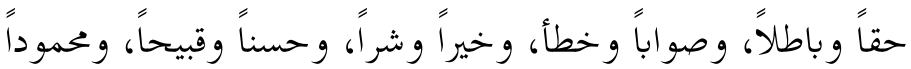

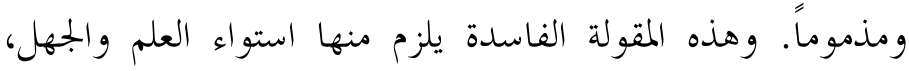
والتوقف عن التفكير والبحث والتجربة، وعدم دعوة الناس إلى العلم الديني أو الدنيوي أو مكارم الأخلاق، كما يلزم منه نشر

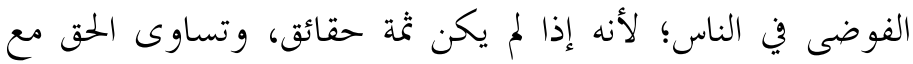

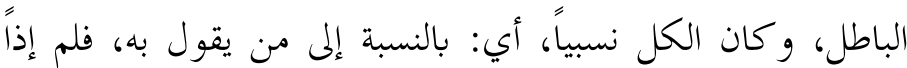

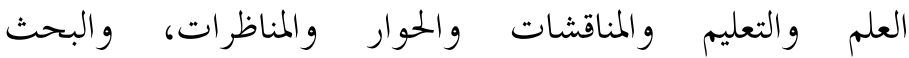

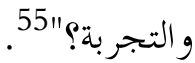

\section{المطلب الثالث: الموضوعية والتقويم والنقد الديني}

دراسة الأديان ومعرفة عقائدها وشعائرها لا تخلو من دراسة نقدية لتحنية

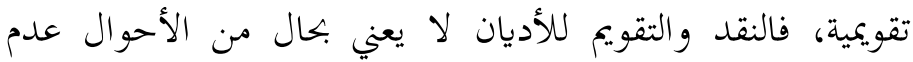

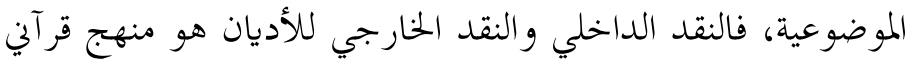

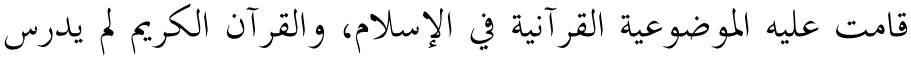

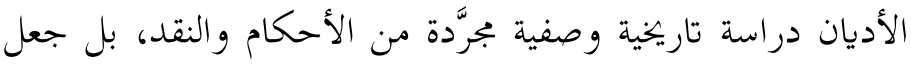

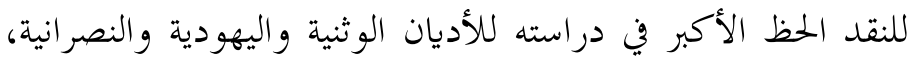

${ }^{55}$ Ibrāhīm ibn Muhammad al-Haqìil, al-Istidlāl al-Khați' bi al-Qur'ān wa al-Sunnah 'alā Qaḍāyā al-Hurriyyah, ed. 1 (Riyadh: Markaz alBayān li al-Buhūth wa al-Dirāsāt, 1434H), 177. 
Abdullah Ahmed, "Objectivity in Religious Study," Afkār Vol. 20 Issue 1 (2018): 229-284

فالموضوعية القرآنية تقوم على نقد العقيدة والشريعة لتلك الأديان،

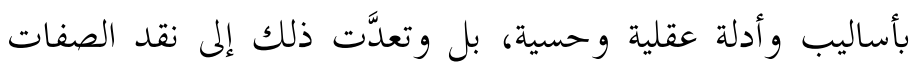

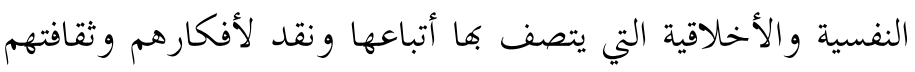
التي هم عليها. والنقد لا يتناقض مع الموضوعية وخصوصاً إذا كان هادفاً

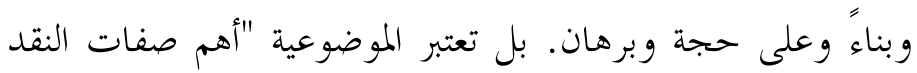

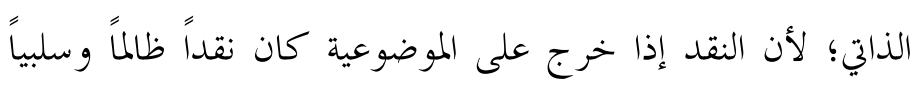

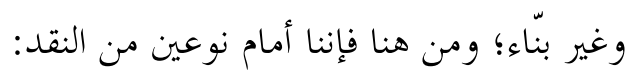

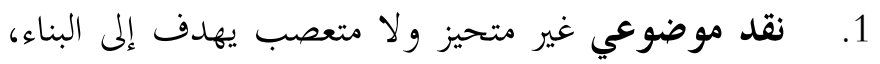
والتغيير والتقدم نحو الأفضل.

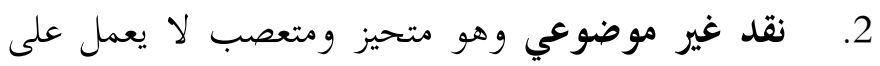

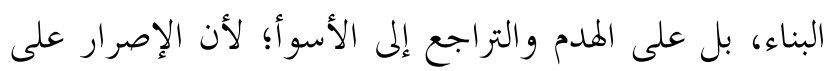
الخطأ خطيئة 56.

والدراسة الموضوعية للأديان تقتضي أن يكون النقد الموجه لها نقداً

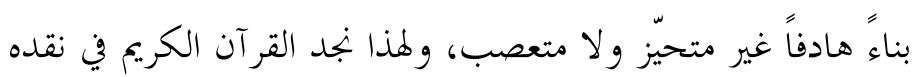

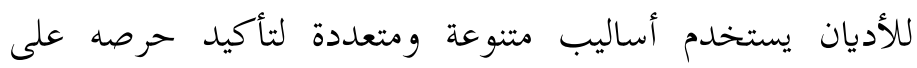

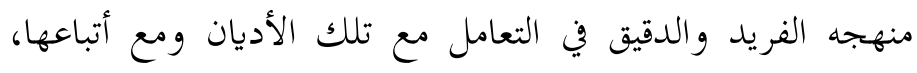
والقائم على هداية البشرية ودعوةما للحق والهدى والنور.

56 Yūsuf 'Umar Qausy, “al-Naqd al-Zātī Khuțwah 'alā al-Ṭarīi", Majallah al-Bayān, No. 115, 24. 
Abdullah Ahmed, "Objectivity in Religious Study," Afkār Vol. 20 Issue 1 (2018): 229-284

يقول الدكتور حسن خليفة مؤ كداً على أهمية النقد وضرورته

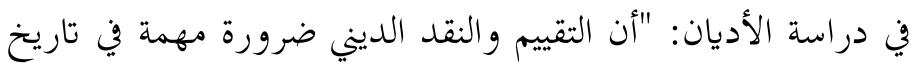

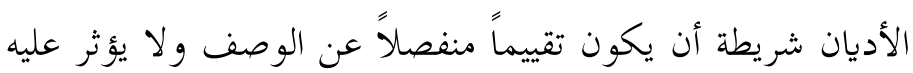

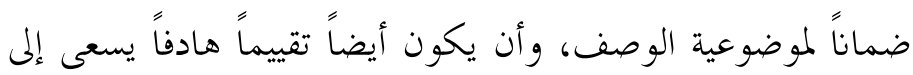
البناء الصحيح لا إلى الهدم والتجريح. وهناك من ون مؤرخي الأديان

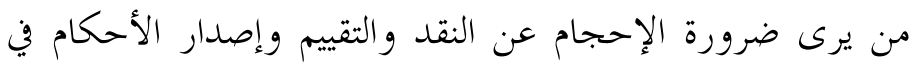

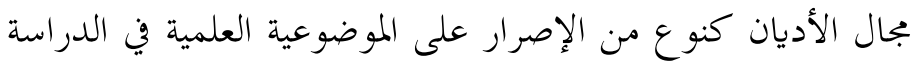

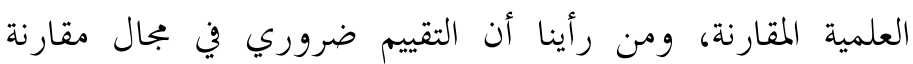
الأديان، ولا يؤثر على مسألة الموضوعية العلمية.

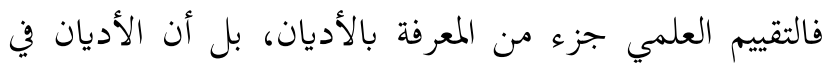
تاريخها استفادت من التقييم والنقد الداخلي والخارجي الذي وجه

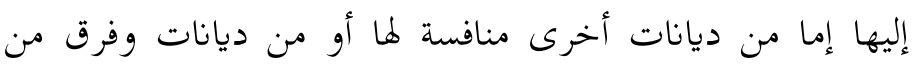

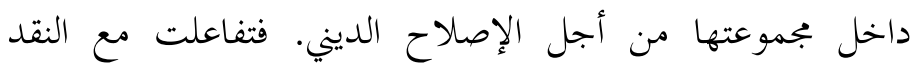

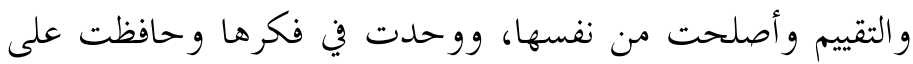
وجودها، وتعايشت في نفس الوقت مع غيرها من الأديان والفرق.

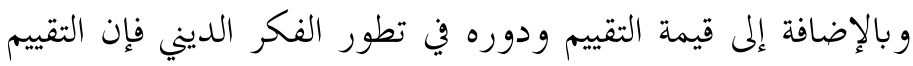
الذي يقوم على أسس علمية وبعيداً عن التعصب الديني فيه فائدة

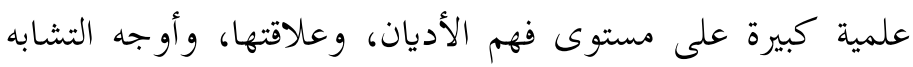

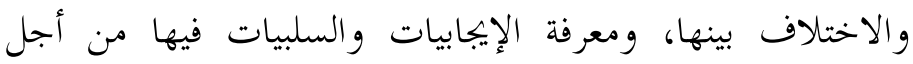


Abdullah Ahmed, "Objectivity in Religious Study," Afkār Vol. 20 Issue 1 (2018): 229-284

الارتقاء بالفكر الديني من ناحية وتحقيق التقدم الروحي للإنسانية

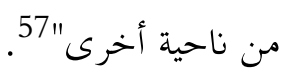

\section{المطلب الرابع: الموضوعية والتجرُّد عن الذات والمعتقد الديني}

يربط البعض بين الموضوعية والتجرد عن الذات والمعتقد الديني،

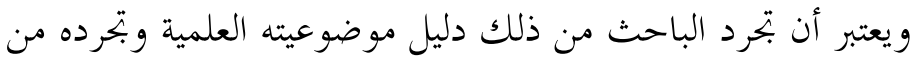

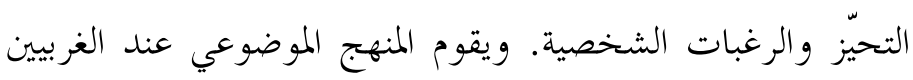

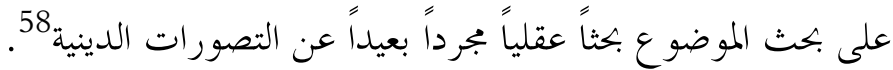
واشتراط التجرد عن الذات والمعتقد الديني والتصورات

كشرط في تحقيق الموضوعية العلمية أمر لا يمكن التسليم به ولا والا قبوله؛ لاستحالة تطبيقه في واقع البحث العلمي؛ لأن "الإنسان

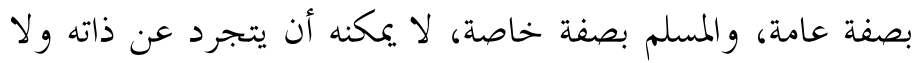

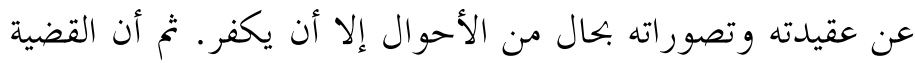
المطلوب التجرد لها وبحثها عقليًا إما أن تكون حقاً أو الو باطلاً، والإنسان لا يعرف الحق من الباطل إلا بواسطة العقيدة الصحيحة،

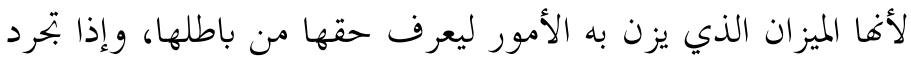

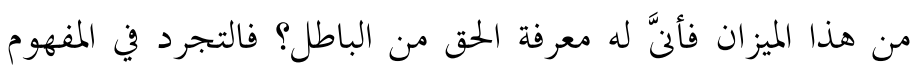

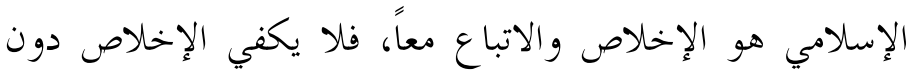

${ }^{57}$ Khalïah, Tārìkh al-Adyān, 17.

${ }^{58}$ Al-Salmî̀, Manhaj Kitāabah al-Tārìkh al-Islāmīi, 135. 
Abdullah Ahmed, "Objectivity in Religious Study," Afkār Vol. 20 Issue 1 (2018): 229-284

اتباع منهج البحث، ولا يكفي الاتباع دون الإخلاص لوجه الله و ابتغاء مرضاته"

والتجرُّد من الهوى والميل وطلب اتباع الأصول العلمية أمور

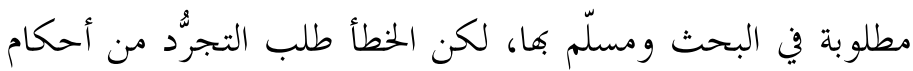
العقيدة فإن ذلك لا يمكنه إلا أن يستبدل بها عقيدة أخرى، كما لهما أنه

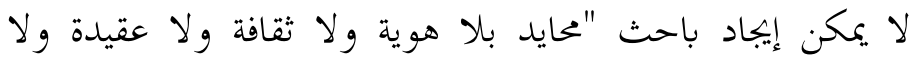

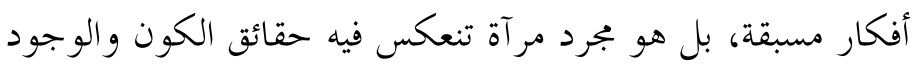

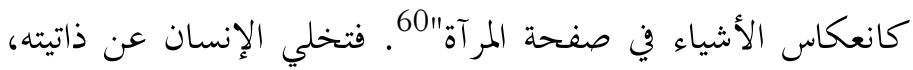

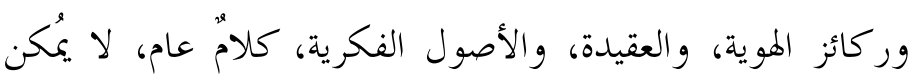
تطبيقه.

وقد قرر الدكتور محمود شاكر في تفنيده لمقولة أن يتجرد

الباحث من كل شيء كان يعلمه من قبل، وأن يستقبل بكثه خالي

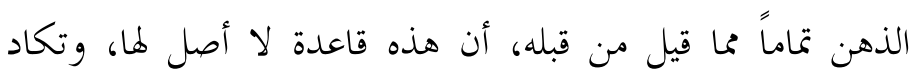

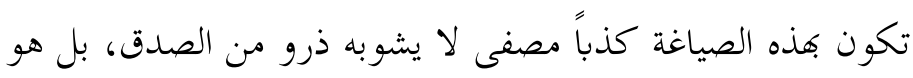

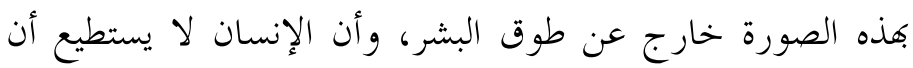

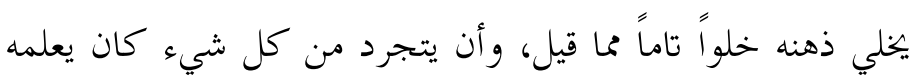

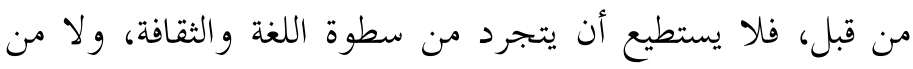

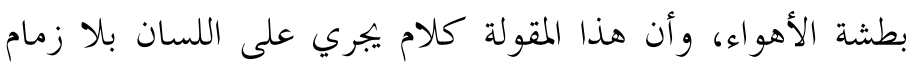

\footnotetext{
${ }^{59}$ Ibid., 137.

${ }^{60}$ Ṭaha Jābir al-'Alwani, “Tașdī̄”, Isykāliyyah al-Tahayyiz.
} 
Abdullah Ahmed, "Objectivity in Religious Study," Afkār Vol. 20 Issue 1 (2018): 229-284

يضبطه أو يكبحه، معصوله أن يتطلب إنساناً فارغاً خاوياً مكوناً من عظام كسيت جلداً لا أكثر 61. إن المقصود في البحث العلمي وخصوصاً في دراسة الأديان أن تتطلب الموضوعية "الحياد المنهجي" لا "الحياد الوجودي"، فللباحث إيمانه الخناص وقناعاته الشخصية، وتصوراته الفكرية

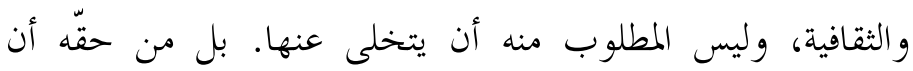

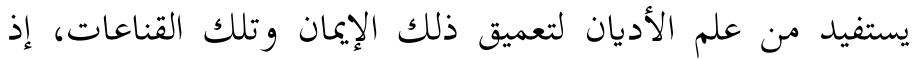
ليس المطلوب منه "الحياد الوجودي". أما "الحياد المنهجي" فيتمثَّل

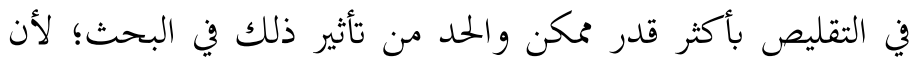

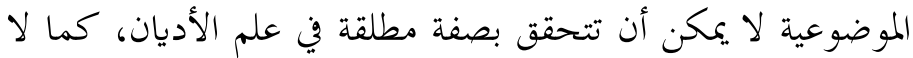

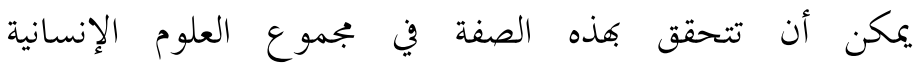
والاجتماعية. لكن الخطاب العلمي هو ذاك الذي يضع الموضوعية

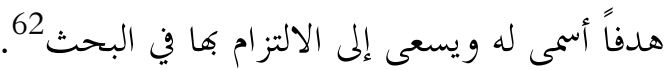

\section{المطلب الخامس: هل يمكن دراسة الأديان دراسة موضوعية؟}

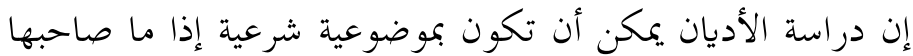

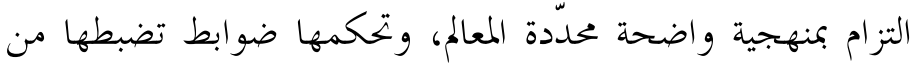

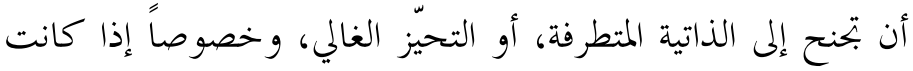

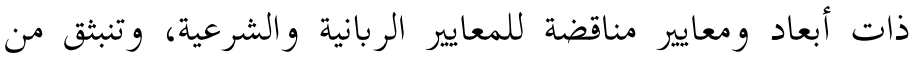

${ }^{61}$ Maḥmūd Muḥammad Shākir, Risālah fī al-Tarìq ilā Thaqāfatinā, (Cairo: al-Hai'ah al-Mișriyah al-'Āmah li al-Kitāb, t.t.), 27-29.

${ }^{62}$ Al-Hadād, Tajārib Kawniyyah fì Tadrìs al-Adyān, 65-66. 
Abdullah Ahmed, "Objectivity in Religious Study," Afkār Vol. 20 Issue 1 (2018): 229-284

معرفة ذات أصول ورؤى أجنبية عن ثقافتنا الإسلامية ومعارفنا

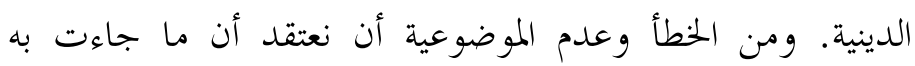
المعرفة العقلية من مبادئ وضوابط ومحدّدات للموضوعية أكثر وثوقاً ومصداقية وموضوعية من المعرفة الدينية المنبثقة من مصادر ربانية

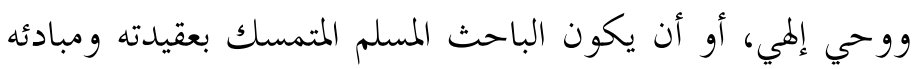

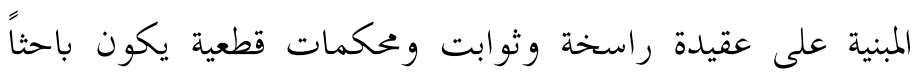

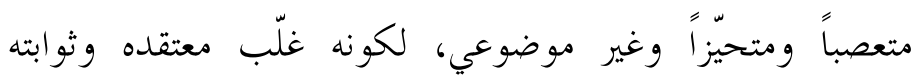

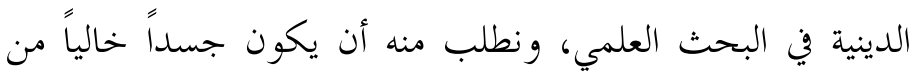
المعتقدات والثقافات والقناعات الشخصية بل والتفكير حتى يسلّم له اله بالحياد وعدم التحيز، ولبحثه بالموضوعية العلمية. فأي منهجية

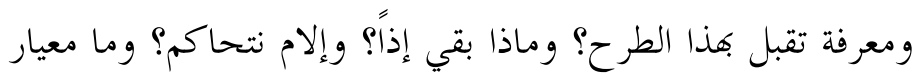

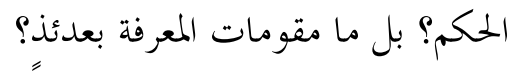

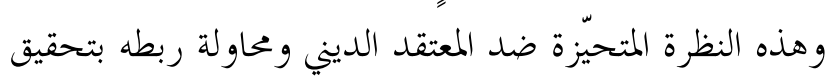
الموضوعية تنم عن خلفية عدائية للدين ولثوابته الشرعية، وبتعل منه وله

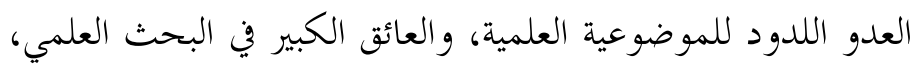

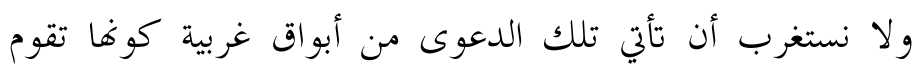

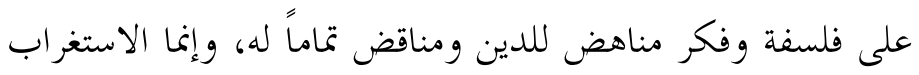

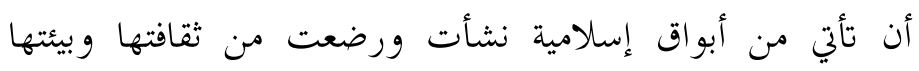

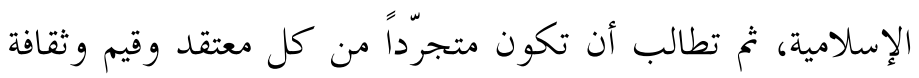
حتى توصف بالموضوعي في التفكير والبحث العلمي، قال تعالى : 
Abdullah Ahmed, "Objectivity in Religious Study," Afkār Vol. 20 Issue 1

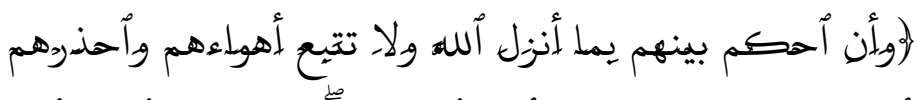

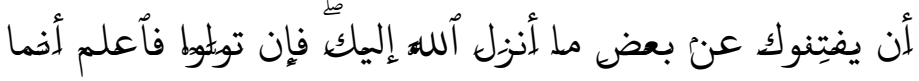

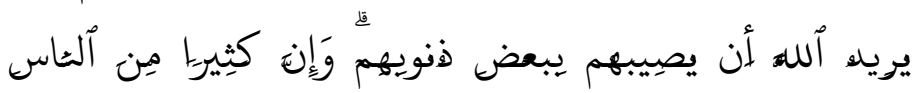

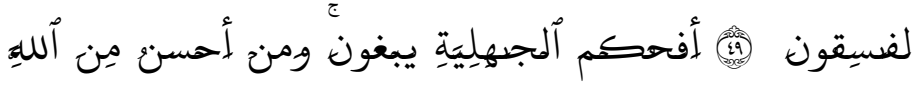

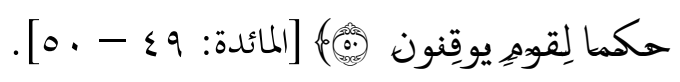

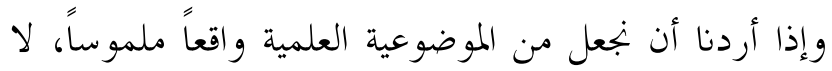

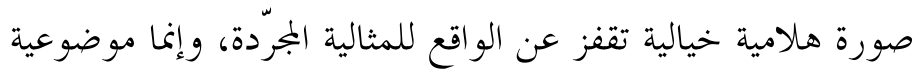

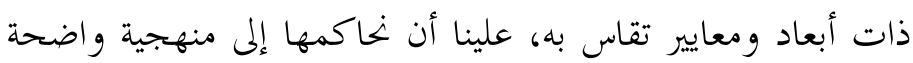

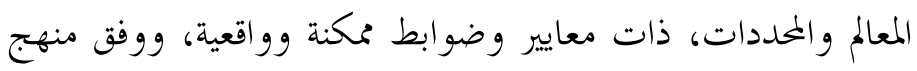

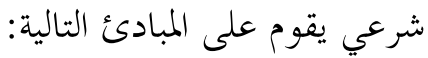
1. إن تكون العقيدة الإسلامية وأصولها ومبادئها هي الحاكمة لمبادية

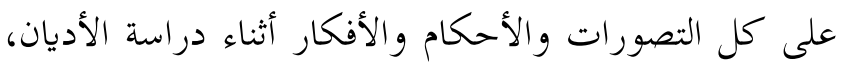

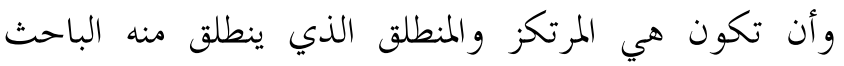
المسلم في دراسته ونقده وتقييمه وحكمه على أي ظاهرة يقوم

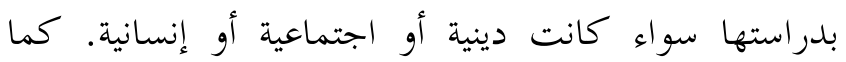
يجب الالتزام بمنهجية القرآن الكريم وموضوعيته في دراسة إنداء الأديان كونه رباني المصدر الذي له حق الصدارة والموثوقية في لهرئ مصدره وأحكامه وتشريعاته، والمحفوظة من التحريف والتغيير

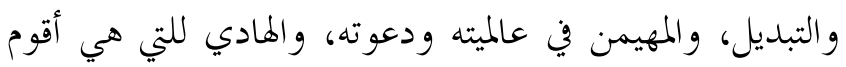
في كل شؤون الحياة ونواحيها المختلفة. 
Abdullah Ahmed, "Objectivity in Religious Study," Afkār Vol. 20 Issue 1

2. علم الأديان علم شرعي يقوم على دوافع إيمانية وأسس

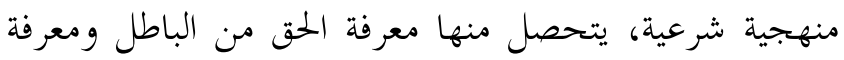

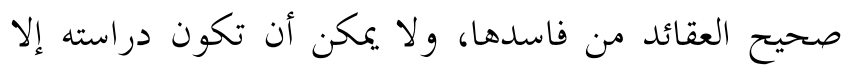

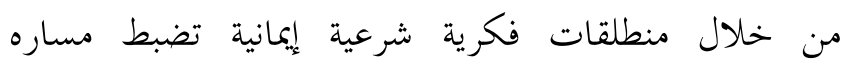
وتوضح معالمه وتحدد طريقه، كما ينبغي التركيز في العرض

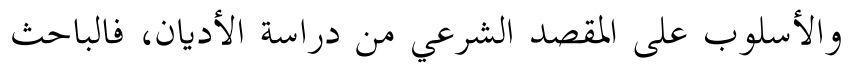
المسلم في دراسته للأديان عليه أن يستحضر معاني العبودية لله عز وجل المتمثلة في بيان الحق ونصرته، وكشف لف لبن الباطل ودحضه، وبيان الصحيح من الفاسد من التصورات و والعقائد،

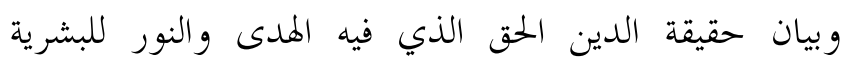
والدعوة إليه، وإظهار محاسنه في العقائد و الشر ائع. 3. الالتزام بمرجعية علمية شرعية تقوم على أساس الوحي الإلهي

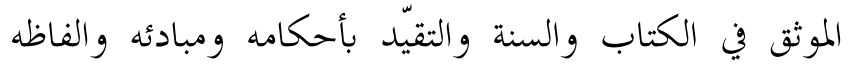

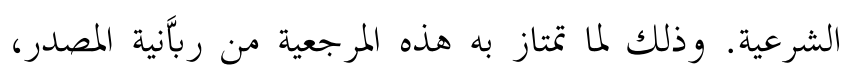

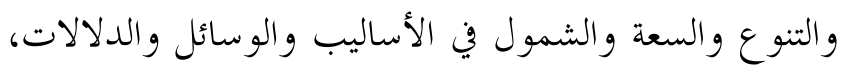

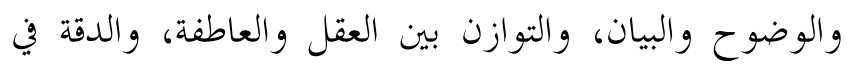

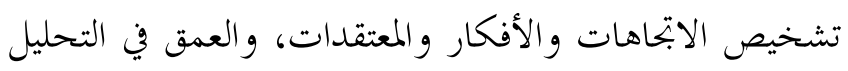
الأحداث وتشخيص الظواهر.

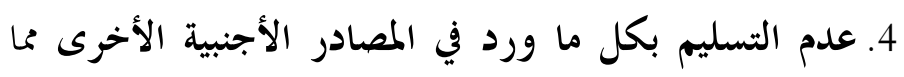

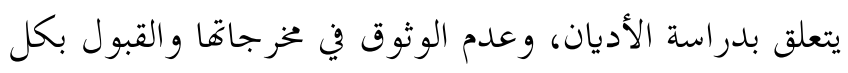


Abdullah Ahmed, "Objectivity in Religious Study," Afkār Vol. 20 Issue 1 (2018): 229-284

ما قرروه من قواعد ونظم ومبادئ إلا بعد النظر فيها وميزاها بميزان الشرع، فما كان فيها من حق وهدى وخير موافق للشرع قبلناه وأخذنا به واستفدنا منه، وما كان فيها من مخالفات ومغالطات تعارض الشرع وتناقضه رفضناه ولا نقبله. وما لا يوافق ولا يخالف فإنه يخضع لموازين النقد العلمي.

5. التقيد بالألفاظ الشرعية، وإطلاقاتما في الشرع، و وتنزيلها منزلتها الصحيحة المعتبرة شرعاً، و البعد عن الألفاظ الحادثة في دراسة الأديان، إذ إن دراسة الأديان والحكم عليها، وبيان صحيحها من فاسدها، وحقها من باطلها، نوع من الحكم الشرعي، ولابد أن يستقيم على الفاظ الشرع المعتبرة. ووجب على الباحث المسلم ألا يظهر الباطل بمظهر الحق، ولا يظهر الخير بمظهر الشر، وإنما يسمي الأشياء بمسمياتما الشرعية ووفق ميزان شرع الله. فالالتزام بالمصطلحات الشرعية له دلالتها العميقة في النفس المؤمنة وتعطيها بُعدها الأخلاقي السلوكي في واقع الحياة العملية. 6. التعمّق في دراسة الدين الحق والعقيدة الإسلامية الصحيحة العملية من مصادرها الموثوقة، و اعتبار ذلك مقدّم وأولوية عظمى قبل دراسة الأديان الأخرى والتعرف عليها. إذ إن توحيد الله وعبادته وإقامة الدين الخالص وبناء المعتقد الصحيح هو الغاية 
Abdullah Ahmed, "Objectivity in Religious Study," Afkār Vol. 20 Issue 1 (2018): 229-284

من دعوة ورسالة الإسلام، وهو الأصل الأول الذي يجب على

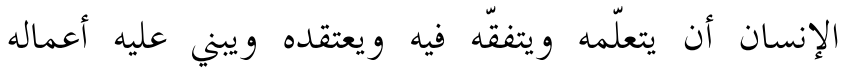
الباطنة والظاهرة عليه. فإذا ارتوى من العقيدة الإسلامية

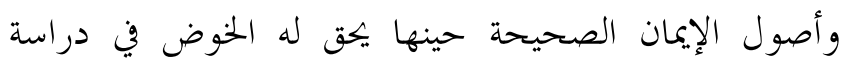
الأديان الأخرى والتعرف عليها.

7. الحرص على هداية الحلق والدعوة إلى الدين الحق، تمثل غاية الدرية

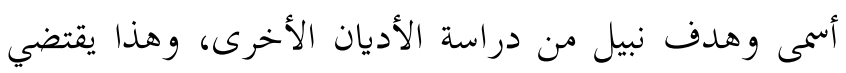

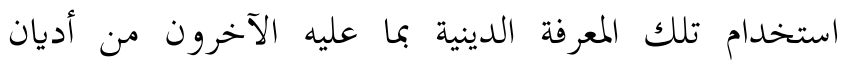
ومعتقدات، في دعوتم وطلب هدايتهم ونصيحتهم، ومجادلتهم ومناظرتم بالتي هي أحسن، ليفوزوا بسعادة الدنيا والآخرة.

الخاتمة

لقد اهتم القرآن الكريم بدراسة الأديان، والتركيز على جملة من القضايا المرتبطة بها، سواء في الجانب العقدي أم في الجانب التعبدي

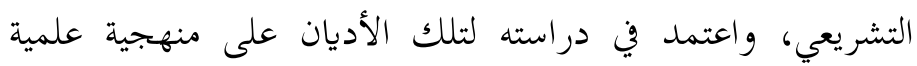
وموضوعية ربانية متميزة لا مقارنة بينها وبين ما جاء في دراسات

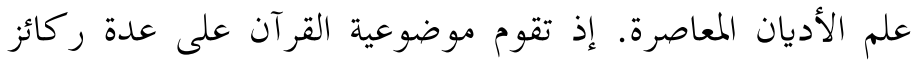

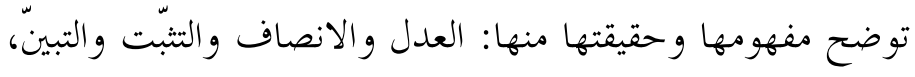

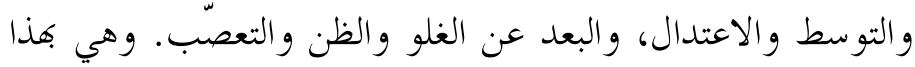

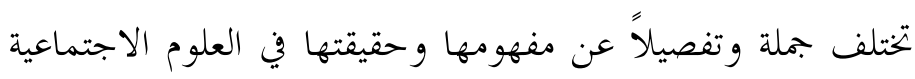
والإنسانية والبحث العلمي المعاصر. 
Abdullah Ahmed, "Objectivity in Religious Study," Afkār Vol. 20 Issue 1 (2018): 229-284

ونظراً لما يواكب الباحث في دراسة الأديان من تحيّزات و تأثيرات نفسية وفكرية ووجدانية وأيديولوجية مما ينعكس سلباً على دراسته وبكثه، وضع القرآن الكريم جملة من الضوابط المتميزة

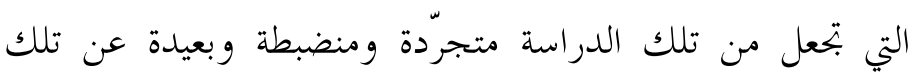

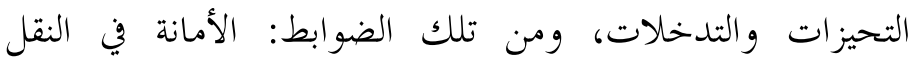
والتوثيق، والعلم والمعرفة، والشهادة بالحق والصدق، والبعد عن

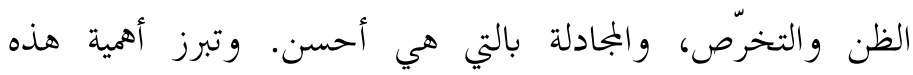
الضوابط في الوقت الحاضر الذي يتسم بالصراع الديني والحضاري

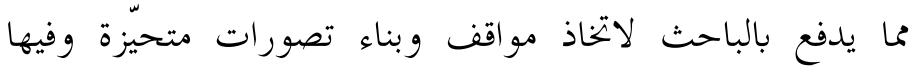
تعدي وظلم فيها نصرة لمعتقده ودينه دون علم وبصيرة وفقه

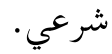
وترتبط الموضوعية في دراسة الأديان بعدد من الإشكاليات التي قد تفهم أها تعارض الموضوعية وتناقضها من مثل: إصدار

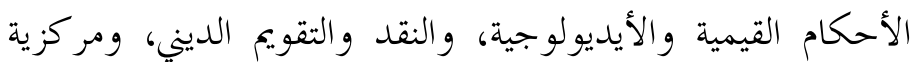

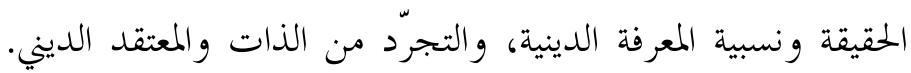

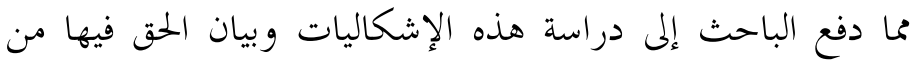
وجهة نظر الموضوعية في القرآن الكريم، والتي اختلفت عنها في الدراسات الدينية المعاصرة ومناهج البحث العلمي في العلوم الاجتماعية والإنسانية. وأثبتت الدراسة أن الموضوعية في دراسة الماتئ

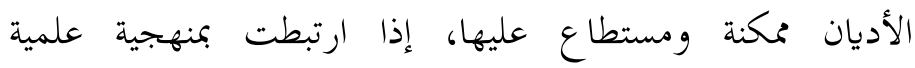


Abdullah Ahmed, "Objectivity in Religious Study," Afkār Vol. 20 Issue 1 (2018): 229-284

وموضوعية شرعية تقوم على عدة مبادئ تتعلق بالتصور والاعتقاد،

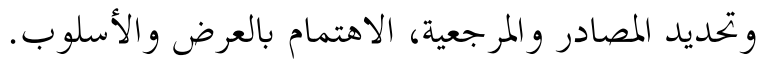
وبعد الدراسة والتحليل لمفهوم وحقيقة الموضوعية في دراسة

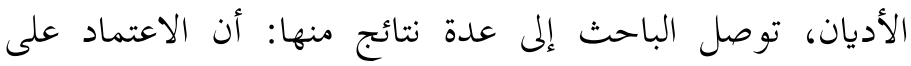
المصطلحات الحادثة الوافدة من الغرب والقائمة على الفلسفة

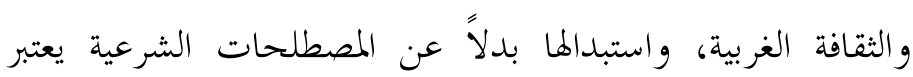
منزلق خطير وله تبعاته السيئة على الثقافة الإسلامية والمعرفة الدينية. وأكّدت على ضرورة الاستقلال والتميز عن مصادر الفكر الغربي في البحث العلمي وفي دراسة الظواهر الإنسانية والاجتماعية

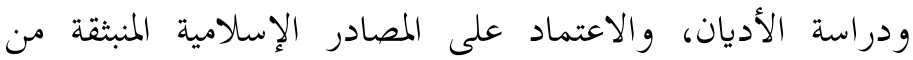

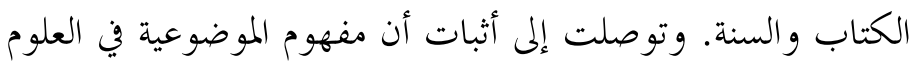
الاجتماعية والإنسانية ومناهج البحث العلمي في الفكر الغربي الغربي يصعب تطبيقه في الواقع بل يكاد يكون مستحيلاً.

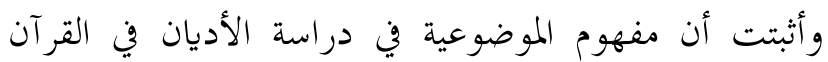

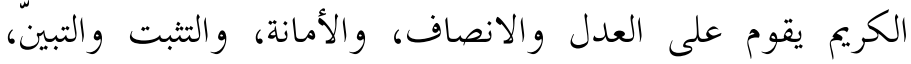
و البعد عن الظن والغلو والتعصب. وهي بهذا المفهوم تختلف تماماً

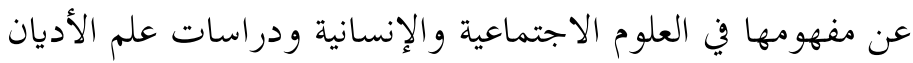

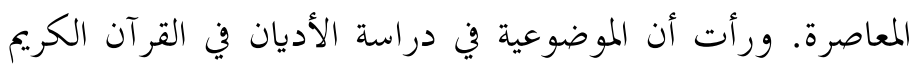
منضبطة بضوابط شرعية تحد من التحيّزات الذاتية والتأثر بالأفكار

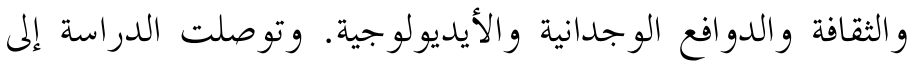


أن الموضوعية في دراسة الأديان لا تتعارض مع إصدار الأحكام

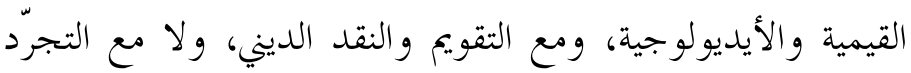

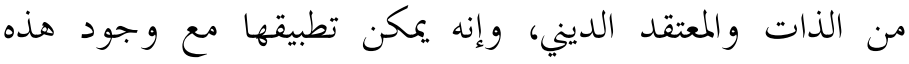

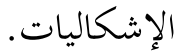

وفي الأخير رأت الدراسة أن الموضوعية في دراسة الأديان

ممكنة ونستطيع تحقيقها إذا كانت تقوم على منهجية علمية وتستند رئد إلى مرجعية ومعرفة شرعية في التصور والاعتقاد وفي العرض

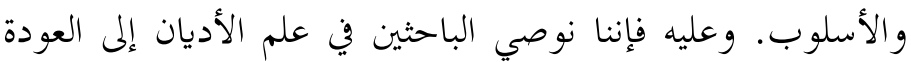

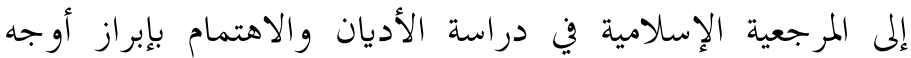
التميز والاستقلال الذي تميز دراسة الأديان في الفكر الإسلامي عنها في الفكر الغربي. وأن يهتم الباحثون بتأصيل هذا العلم من الناحية

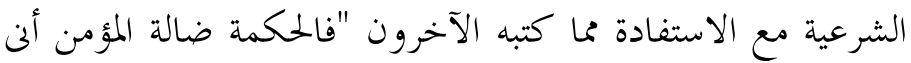

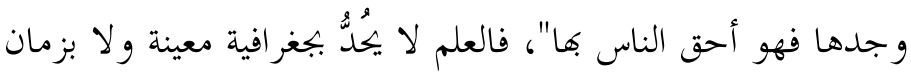
و لا مكان محدود.

\section{References}

'Abd al-Hādī, Mas‘ūd Jamāl and Muhammad Rafa'at, Jum'ah Wafā. Manhaj Kitābah al-Tārikh al-Islämì Limā dhāa? Wa Kayf? ed. 3. Al-Manșūrah: Dār al-Wafā, $1414 \mathrm{H} / 1994$.

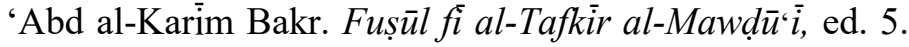
Damascus: Dār al-Qalam, 1429H/2008.

'Abd Allah, 'Abd al-Rahmōan ibn Șālih. Al-Mawdūu'iyyah fí al-'Ulūm al-Tarbawiyyah Ru'yah Islāmiyyah, ed. 1. Jeddah: Dār al-Manārah, 1407H. 
'Abidīn, Țāha et al. Al-Hidāyāt al-Qur'āniyyah Dirāsah Ta'șìliyyah, ed. 1. Damām: Maktabah al-Mutanabbì, $1438 \mathrm{H} / 2017$.

Abd al-Razzāq 'Abd Allāh Hash, "'Ilm Muqāranah alAdyān bayn Su'āli al-Mafhūm wa al-Mawḍ̄̄iyyah", Islāmiyah al-Ma'rifah, al-Sunnah, 17, No. 67.

Badwì, Ahmmad Zakí. Mu'jam al-'Ulūm al-Ijtimā'iyyah.

Beirut: Maktabah Lubnan, t.t.

Al-Buhansì, Aḥmad Șalāḥ. Al-Qur'ān al-Karīm wa 'Ulūmuh fì Mawsū'àt al-Yahūdiyyah, ed. 2. Riyadh: Markaz Tafsīr li al-Dirāsāt al-Qur'āniyyah, $1436 \mathrm{H} / 2015$.

Duwaydarī, Rajā' Wahịid. Al-Bahth al-'Ilmì Asāsiyātuh alNadhriyyah wa Mumārasatuh al-'Ilmiyyah, ed. 1. Beirut: Dār al-Fikr al-Mu‘āṣir, 1421H/2000.

Al-Ḥaqìl, Ibrāhīm ibn Muhammad. Al-Istidlāl al-Khațí' bi al-Qur'ān wa al-Sunnah 'alā Qad̄àyā al-Hurriyyah, ed. 1. Riyadh: Markaz al-Bayān li al-Buhūth wa al-Dirāsāt, 1434H.

Al-Ḥadād, Muhammad. Tajārib Kawniyyah fī Tadrīs alAdyān, ed.1. Dubai: Markaz al-Musābar li al-Dirāsāt wa al-Buhūth, 2014.

Al-Ḥāfī, 'Umar, "al-Mawḍū'iyyah fī Dirāsah al-Adyān", Islāmiyah al-Ma'rifah, 15, No. 60.

Al-Harawi al-Azhari, Muhammad ibn Ahmad. Tahzīb alLughah, ed. Muhammad Awaḍ Mur'ib, ed. 1. Beirut: Dār Ihyyā' al-Turāth al-'Arabī, 2001.

Hijāzì, Muhammad Maḥmūd. Al-Wahdah al-Mawdū 'iyyah fì al-Qur'ān. Cairo: Mațba'ah al-Madani, 1390H/1970.

Ibn Kathīr, Abū Fidā' Ismā'ìl ibn 'Umar. Tafsìr al-Qur'ān al-'Azìim, ed. Sāmí ibn Muhammad Salāmah. Riyadh: Dār Tayyibah, 1420H/1999.

Ibn Manzeūr, Abū al-Fadhl Muhammad ibn Mukarram. Lisān al-'Arab, ed. 3. Beirut: Dār Șādir, 1414H.

Khalïfah, Muhammad. Tārīkh al-Adyān. Cairo: Dār alThaqāfah al-'Arabiyyah, 2002. 
Madkūr, Ibrāhīm. Mu'jam al- 'Ulūm al-Insāniyyah. Cairo: al-Hay'ah al-'Āmah al-Mișriyyah li al-Kutub, t.t.

Al-Mawsū'ah al-'Arabiyyah, al-Mawdū'iyyah, accessed 12 Oct 2017, https://www.arab-ency.com/ar.

Al-Musayrī, 'Abd al-Wahhāb. Mawsū'ah al-Yahūd wa alYahüdiyyah wa al-Ṣahyūniyyah, ed. 1. Cairo: Dār alShurūq, 1999.

Qansūh, Șalāḥ. Al-Mawdū 'iyyah fī al- 'Ulūm al-Insāniyyah, ed. 2. Beirut: Dār al-Tanwïr, 1984.

Qausy, Yūsuf 'Umar, "al-Naqd al-Zātì Khuțwah 'alā alȚariq", Majallah al-Bayān, No. 115.

Al-Rāghib al-Aṣhfahānī, Abū al-Qāsim al-Husayn ibn Muhammad. Al-Mufradāt fī Gharīb al-Qur'ān, ed. Șafwān 'Adnān al-Dawdì, ed. 1. Beirut: Dār al-Qalam, $1412 \mathrm{H}$.

Rashād, Khalīl Muhammad. Al-Manhaj al-Islāmī li Dirāsah al- Tārīkh wa Tafsīruh, ed. 1. Cairo: Dār alManār, 1404H/1984.

Al-Salmī, Muhammad Șāmil. Manhaj Kitābah al-Tārīkh al-Islāmì, ed. 1. Al-Damām: Dār Ibn Jawzì, 1429H.

Shākir, Mạ̣mūd Muḥammad. Risālah fî̀ al-Ṭarīq ilā Thaqāfatinā. Cairo: al-Hai'ah al-Mișriyah al-'Āmah li al-Kitāb, t.t.

Al-Shanqiți, Muhammad al-Amin al-Mukhtār. Ad $w \bar{a} \bar{a}$ ' alBayān fì Ị̇āh al-Qur'ān bi al-Qur'ān. Beirut: Dār alFikr, 1415H/1995.

Al-Sufyānī, Muḥammad ibn Basīs. Al-Asas alManhajiyyah li naqd al-Adyān Dirāsah fí Su'āl alManhaj wa Nazariyah al-Bahth, ed. 1. Jeddah: Markaz al-Ta'șil li al-Dirāsāt wa al-Buhūth, 1437H/2016.

Al-Suhaybāni, 'Abd al-Majīd ibn 'Abd al-Raḥmān. Kayf Nata'āmal ma'ā Ghayr al-Muslimīn, ed. 1. Riyadh: Madār al-Wațan li al-Nashr, 1436H/2015.

Al-Ṭabari, Muhammad ibn Jarīr. Jāmi al-Bayān fī alTa'wīl al-Qur'ān, ed. Aḥmad Muhammad Shākir. Beirut: Mu'assasah al-Risālah, 1420H/2000. 
Al-'Umayrī, Șultān ibn 'Abd al-Raḥmān. Șinā'ah alTafkìir al-'Aqdī, ed. 1. London: Takwin li al-Dirāsāt wa al-Abhath, 1435H/2014.

'Umar, Aḥmad Mukhtār. Mu'jam al-Lughah al'Arabiyyah al-Mu'āṣirah, ed. 1. Cairo: 'Ālim al-Kutub, $1429 \mathrm{H} / 2008$.

Al-Zawādī, Maḥmūd. Mulāmah al-Tahayyiz wa alMawd̄ìiyyah fí al-Fikr al-Ijtimā iyyah al-Insāni alGharbi al-Khaldūni, Ru'yah Ma'rifiyyah wa Da'wah li al-Ijtihād, ed. 2. America: al-Ma'had al-'Ālami li alFikr al-Islāmi, 1418H/1997.

Al-Zuhaylī, Wahbah ibn Mustafā. Al-Tafsìir al-Wasiț, ed. 1. Damascus: Dār al-Fikr, 1422H.

Al-Zunaydi, 'Abd al-Raḥmān Zayd. Al-Salafiyyah wa Qadāyā al-'Aṣr, ed. 1. Riyadh: Dār Ishbalia li al-Nashr, $1418 \mathrm{H}$. 
Abdullah Ahmed, "Objectivity in Religious Study," Afkār Vol. 20 Issue 1 (2018): 229-284 